\title{
THE DIVORCE ACT (CANADA), 1968
}

\author{
JULIEN D. PAYNE*
}

Canada's new Divorce Act came into force on July 2, 1968. In this article the author surveys in numerical sequence the sections of the Act and advances his opinion as to how they will be interpreted.

\section{Definition of Scope of Paper}

In the following general survey of the provisions of the Divorce Act (Canada), 1968, the writer proposes to examine the sections in their numerical sequence.

A comprehensive and authoritative analysis of the sections must necessarily await judicial interpretation of the Act. The interpretations accorded thereto in this paper must therefore be tentatively advanced and are to be regarded as speculative. It is nevertheless hoped that they may provide some basis for a better appreciation of the statute.

\section{Introduction}

The Divorce Act, 1968, received Royal Assent on February 1st, 1968 and came into force on July 2nd, 1968. ${ }^{1}$ It represents the first major revision of the law of divorce in Canada and many of its provisions can be traced to the evidence submitted to and the recommendations of the Special Joint Committee of the Senate and House of Commons on Divorce, which presented its Report to the Parliament of Canada in June, 1967, after receiving more than seventy briefs and holding twentyfour hearings in which the views of churches, organizations and individuals were presented.

The principal changes effected by the Divorce Act, 1968, relate to the extension of the grounds for divorce to include additional matrimonial offences and also designated circumstances resulting in the permanent breakdown of marriage; revision of the established bars to divorce and, in particular, collusion, condonation and connivance; elimination of the traditional discretionary bars to divorce; the introduction of new bars applying to the divorce grounds premised on proof of permanent marriage breakdown; the formulation of revised rules governing jurisdiction in divorce proceedings and recognition of foreign decrees; the definition of obligations whereby counsel and the courts must examine the prospect of reconciliation being achieved between the parties to divorce proceedings; and the imposition of mutual support obligations upon the spouses.

\section{Interpretation}

Section 2 of the Divorce Act constitutes the interpretation section and merits detailed analysis of several of the terms therein defined.

Child; Children of the Marriage

Section 2, paragraphs (a) and (b) define "child" and "children of the marriage" as follows:

(a) 'child' of a husband and wife includes any person to whom the husband and wife stand in loci parentis and any person to whom

- Simon Senior Research Fellow, University of Manchester.

1 Divorce Act. S.C. 1967-68. c. 24. See Proclamation of Divorce Act (Canada) (1968). 102 Canada Gazette (Part I) 1234-1235. 
either of the husband or the wife is a parent and to whom the other of them stands in loci parentis;

(b) 'children of the marriage' means each child of a husband and wife who at the material time is

(i) under the age of sixteen years, or

(ii) sixteen years or over and under their charge but unable, by reason of illness, disability or other cause, to withdraw himself from their charge or to provide himself with necessaries of life.

It will be observed that the term "child" is defined so as to include the illegitimate children of either spouse and the adopted children of either spouse, where such children have been accepted as members of the family at the relevant time.

It is envisaged that difficulties will arise from the use of the phrase "in loci parentis" which is inherently vague and it is perhaps unfortunate that the Parliament of Canada declined to adopt the definition of "child" in section 2 of the Matrimonial Proceedings Act 1963 (New Zealand), wherein the phrase "who was a member of the family of the husband and wife" is preferred to the more nebulous formula "in loci parentis".

Some guidance as to the meaning of the phrase "in loco parentis" may be obtained from judicial decisions. Thus, in Powys v. Mansfield, Lord Cottenham stated:

... No doubt the authorities leave some obscurity as to what is considered to be meant by the expression ... in loci parentis. Lord Eldon, in Ex parte Pye, has given to it a definition, which I readily adopt. ... Lord Eldon says, 'It is a person meaning to put himself in loci parentis, in the situation of the person described as the father of that child.' But this definition must, I conceive, be considered as applicable to those parental offices and duties to which the subject in question has reference-namely, to the office and duties of a parent to make a provision for the child. The offices and duties of a parent are infinitely various, some having no connexion whatever with making a provision for a child; and it would be very illogical, from the mere exercise of any such offices and duties by one not the father, to infer an intention in such person to assume also the duties of providing for the children. . . . Sir William Grant's definitions is, 'A person assuming the parental character, or discharging parental duties,' which may seem not to differ much from Lord Eldon, but I think it wants that, which, to my mind, constitutes the principal value of Lord Eldon's definitionnamely, referring to the intention, rather than to the acts of the party. The Vice-Chancellor says 'It must be a person who has so acted towards the child, as that he has thereby imposed on himself a moral obligation to provide for it,' and it will not hold, when the child has a father, with whom it resides, and by whom it is maintained. Now, this seems to infer that the locus parentis assumed by a stranger must have reference to the pecuniary wants of the children, and that Lord Eldon's definition is so to be understood, and, so far I agree with him; but, I think, the other circumstances required are not necessary. The rule, both as applied to a father, and to one in loci parentis, is founded on presumed intention. If a father is supposed to intend to do that which, in duty, he is bound to do-namely, to provide for his children according to his means, so one who has assumed that part of the office of a father is supposed to do that which he assumed to himself the office of doing. If the assumption of the character be established, the same inference and presumption must follow. His having so acted towards a child as to raise a moral obligation to provide for it, affords a strong inference in favour of the assumption of that character; and, though the circumstances of that child having a father, with whom it resides,

2 Matrimonial Proceedings Act 1963, N.Z. No. 71.

3 (1837), 7 L.J. Ch. 9, 10-11.

4 (1811), 18 Ves. Jun. 141, 154; 34 E.R. 271, 276.

5 Wetherby v. Dixon (1815), 19 Ves. Jun. 407, 412; 34 E.R. 568, 570. 
and by whom it is maintained, afford some inference against it, neither of these circumstances can be considered as conclusive. ${ }^{6}$

Although this judicial definition offers some indication of the interpretation which may be placed upon the expression "in loci parentis" in section 2 (a) of the Divorce Act, it is clear that it compounds the difficulties arising under the section respecting such questions as whether a husband and wife may stand in loci parentis to persons other than their biological or adopted children, e.g., a disabled sister or a grandchild of either spouse who is living in the matrimonial home and is maintained by the spouses. ${ }^{7}$

A further difficulty which may arise by virtue of the definition of "children of the marriage" in section $2(b)$ of the Act relates to the question whether the section may be interpreted to include children over the age of sixteen years who are incapable of maintaining themselves by reason of being engaged in continuing education at school, community college or university. It is conceivable that the provisions of the Act do not extend to such children since the phrase "or other cause" in section 2 (b) (ii) may be interpreted restrictively in light of the preceding words "by reason of illness [or] disability." If such restrictive interpretation of the section were adopted, the legitimate child's right to maintenance under the provisions of the Divorce Act, 1968 would prove less substantial than the statutory right previously accorded in several Canadian provinces. ${ }^{8}$

\section{Collusion}

Section 2 (c) of the Divorce Act provides a definition of collusion in the following terms:

'Collusion' means an agreement or conspiracy to which a petitioner is either directly or indirectly a party for the purpose of subverting the administration of justice, and includes any agreement, understanding or arrangement to fabricate or suppress evidence or to deceive the court, but does not include an agreement to the extent that it provides for separation between the parties, financial support, division of property interests or the custody, care or upbringing of children of the marriage.

o See also Howie v. Lawrence, [1927] 1 D.L.R. 477, 479; 59 O.L.R. 641, wherein the definition set out in 2 Stroud's Judicial Dictionary 1118-1119 was approved and the expression in loci parentis was held to describe a person "who takes upon himself the duties of a father to make provision for a child."

7 See Howie v. Lawren, id., wherein parents who had in fact, although not in law, adopted the illegitimate child of their daughter were held to stand in loci parentis to the child.

See also Powys v. Mansfield, supra, n. 3, where Lord Cottenham stated:

"A rich unmarried uncle, taking under. his protection the family of a brother, who has not the means of adequately providing for them, and furnishing to such father the means of their maintenance and education, may surely be said to intend to put himself, for the purposes in question, in loci parentis to the children, though they may never, in fact, leave their father's roof. An uncle, so taking such a family under his care, will have all the feelings, and intentions, and objects with regard to providing for the children, which would influence him if they were orphans. For the purpose in question/namely, providing for them, the existence of the father can make no difference."

Note: If section 2 (a) were interpreted to include such persons as a disabled sister, statutory obligations of maintenance imposed pursuant to the Divorce Act. s. $11(1)$ could presumably extend beyond the age of majority of the disabled party: Divorce Act, s. 2 (b) (Ii).

8 See Power on Divorce 580 (2d ed., 1964):

"In Fngland the court has the power to make orders in a divorce case for the maintenance of children over 16 and the same power has been held to exist in Alberta New Brunswick and Ontario. The existence of such a power has been questioned in British Columbia; and denied in Saskatchewan unless the trial judge has expressly found and directed that liability for maintenance continue beyond that age."

See also the cases cited therein, especially: Thomasset $v$. Thomasset, [1894] P. 295 63 L.J.P. 140; Le Mare v. Le Mare, [1961] P. 10; [1960] 2 W.L.R. 952; [1960] 2 Al] E.R. 280 (wherein it was held that the court has power under (Imp.), 14 Geo. the Matrimonial Causes Act 1950,6 c. 25, s. 26(1) to order unsecured maintenance for a child beyond the age of twenty-one years): Ferguson v. Ferguson, 11949] 2 W.W.R. 879 (Alta.); Firman v. Firman, [1951] O.W.N. 66; R. v. Rednar (1898), 6 B.C.R. 73; Faustman v. Faustman and Everett (1952-53), 7 W.W.R. (N.S.) 373. 
The clause in section 2 (c), whereby collusion in defined to exclude an agreement which provides for separation between the spouses was presumably inserted in consequence of section (4) (1) (e) (i) of the Act which introduces the right to divorce on proof of permanent marriage breakdown by reason of the spouses having lived separate and apart for three years immediately preceding presentation of the petition. Beyond this modification of the law, the definition of collusion in section 2 (c) could be regarded as declaratory of the law previously established by judicial decisions. Thus, it is perhaps not without significance that the positive or inclusionary aspect of the statutory definition in section 2 (c) substantially corresponds to the definition of collusion formulated by Norris, J., in Johnson v. Johnson and Arnet, ${ }^{0}$ who stated:

Collusion may be:

(a) Any agreement or conspiracy, to which the petitioner is a party which, as in this case (in the covenant not to defend the action) tends to pervert or obstruct the course of justice;

(b) Any agreement or conspiracy, to which the petitioner is a party to obtain a divorce by means of manufactured evidence:

(c) Any agreement or conspiracy, to which the petitioner is a party to obtain a divorce by some fraud or deceit practised on the court.

Furthermore, the negative or exclusionary aspect of the statutory definition in section 2 (c) may be regarded as merely reflecting the opinion of Denning, J., as he then was, in Emanuel v. Emanuel ${ }^{10}$ where he stated that the "petitioner must not be a party to any arrangement which perverts or tends to pervert the course of justice" but added:

This does not mean that, after a matrimonial offence has been committed ...., the parties may not discuss the problems created by it. The law favours reconciliation and permits separation agreements. It cannot prevent the parties from considering the remaining alternative of divorce. If reconciliation is impossible, there are many matters to be considered such as the future of the children, the house and furniture, and the provision of maintenance and necessaries for the wife. Such matters must be dealt with either by agreement or by the court. If a separation has actually occurred or becomes inevitable, the law permits the parties to make a separation agreement which makes provision for such matters, see Fender v. Mildmay, [ [1938] A.C. 1, 44]. So also if one party has started divorce proceedings or has decided to start them, the law permits the parties to make arrangements about such matters so long as they are made in good faith and with reasonable cause.

Even before an innocent party decides on divorce he or she may be faced with a difficult position. Take the case of an innocent wife. If her guilty husband is desirous of divorce he may provide evidence, offer maintenance and costs and generally do all he can to persuade her to bring proceedings. She cannot stop him; and it is not every wife who can be expected to disregard such conduct. It may convince her that divorce is the only remedy for the situation that he has created, so that she accedes to his wish, decides to start proceedings and accepts his offer, but that by itself is not collusion, see Beattie v. Beattie [,[1938] $P$. 99]. If she stoops, however, to accept a bribe that is collusion, because the court cannot be sure that she genuinely seeks relief.

... If a petitioner accepts a bribe, or extorts one, as an inducement to bring or carry on proceedings, or if she bribes a respondent not to defend, that is collusion. In bribery, as in extortion, innocence or guilt depends on whether the inducement is offered or sought with reasonable cause or not. The line may often be difficult to draw. The provision by a guilty husband of an allowance for his wife or her costs may be merely the provision of necessaries to which he is entitled by law; but if he pays her a large sum in cash it excites a suspicion that it is the price of his freedom."1

Similarly a husband who stipulates for an excessive sum as damages from the co-respondent raises the suspicion that it is the price he asks for giving his

o (1960), 31 W.W.R. (N.S.) 403, 415; 23 D.L.R. (2d) 740 (B.C.).

10 [1946] 'P. 115; [1945] 2 All E.R. 494; 114 L.J.P. 60.

11 See also Johnson v. Johnson and Arnet, supra, n. 9, at 419, wherein Norris, J., stated: "It is to be noted that an arrangement which it is suggested is collusive may stlll be collusive notwithstanding the fact that it relates to something-costs, for example, or maintenance-with regard to which the wife had rights, which she could enforce." 
wife her freedom. . . . Conversely the fact that a wife does not claim maintenance, or costs, may be simply because she has means of her own: but if she foregoes or agrees to forego her claims in return for the withdrawal by the husband of a defence on the merits, reasonable cause would be hard to find. The fact that a husband does not claim custody of children or damages gives rise to no suspicion: but if he agrees to forego his children or damages in return for a promise not to defend the suit on its merits, that may be collusion as it was in Churchward v. Churchward [,[1895] P. 7].

Notwithstanding the above decisions, however, it is by no means obvious that section 2 (c) is merely declaratory of the law. It is possible, therefore, that the Canadian courts will restrictively interpret the statutory definition which explicitly requires proof of "an agreement or conspiracy ... . [to subvert] the administration of justice," and that conduct which would formerly have been regarded as collusive will not now, in the absence of proof of an intention to cause a perversion of justice, be so regarded. Such a restrictive interpretation of section 2 (c) would conform to the current judicial trend in Australia and New Zealand. ${ }^{12}$ Section 40 of the Matrimonial Causes Act 1959 (Australia) ${ }^{13}$ provides that a decree of dissolution of marriage must be denied by the court if the petitioner, in bringing or prosecuting the proceedings, has been guilty of "collusion with intent to cause a perversion of justice."14 In interpreting this section, the Australian courts would appear to have defined collusion more narrowly than was previously the case so that the conduct now necessary to produce a finding of collusion is of the same nature as a criminal conspiracy. ${ }^{15}$ In Bell v. Bell, ${ }^{10}$ Joske, J., observed:

Since the Commonwealth Matrimonial Causes Act 1959, the whole notion of collusion as a bar to divorce has been altered. ... Under the Commonwealth Act, collusion is a bar to divorce only if the petitioner . . has been guilty of collusion with intent to cause a perversion of justice' (sec. 40). This involves an agreement between the parties and an agreement which involves a common intent to cause a perversion of justice. If one party only has that intent and the other has not, the parties are not of the one mind and it cannot be said that an agreement made by them is made with intent to cause a perversion of justice.

And in Grose v. Grose, ${ }^{17}$ Begg, J., stated:

The law is, I think, still not fully defined at present as to what amounts to a collusive agreement which would be in breach of $s .40$ of the Matrimonial Causes Act 1959. (Com.). This section requires the Court not to pronounce a decree if it finds there has been collusion with the intent to pervert the course of justice. It seems to me that collusion would at least arise in the following types of cases. First, where a party undertakes to provide false evidence in the procuring of a divorce; obviously this would be collusion. Secondly, it might arise where the effect of the agreement, and indeed the intention of the agreement, was to suppress evidence in a court which would result in a different order being made by the court than the order contemplated. Thirdly, it would seem to me to arise in cases where a defence is abandoned for a consideration. That is in cases where parties agree not to urge a substantial and bona fide defence which would, by virtue of that agreement, deprive the Court of an opportunity of fulfilling its statutory functions of determining the issues involved and which would lead to a decree or order being improperly obtained. ... In $\mathrm{s}$. 40 the critical word used is 'intent'. Before a court could come to the conclusion that it should dismiss the petition and refuse dissolution of marriage, it would have

12 See Shaw v. Shaw (1965), 6 F.L.R. 455; Grose v. Grose, infra, n. 17; Bell v. Bell, infra, n. 16: Barrott v. Barrott, [1964 | N.Z.L.R. 968.

13 Matrimonial Causes Act 1959, Aust. No. 104.

14 See also Matrimonial Proceedings Act 1963. supra, n. 2, s. 31, whereby "collusion between the petitioner and respondent with intent to cause a perversion of justice" constitutes a discretionary bar to divorce.

15 See P. B. Toose, The Matrimonial Causes Act, 1959 (1961), 34 Aust. L.J. 247, 254. See also D. M. Selby, The Development of Divorce Law in Australia (1966), 29 Mod. L. Rev. $473,486$.

16 [1964] A.L.R. 29; 4 F.L.R. 274, 276.

17 [1965] A.L.R. 1151: [1965] N.S.W.R. 429. 
to find that there had been an intention to cause a perversion of the course of justice.

Since section 2 (c) defines collusion as an agreement or conspiracy entered into "for the purpose of subverting the administration of justice," it may reasonably be inferred that proof of a mutual intention of the parties to subvert the administration of justice is a prerequisite to any finding of collusion. If this assumption is correct, it would follow that the Canadian courts might well adopt the reasoning of the Australian courts and interpret section 2 (c) of the Divorce Act in such an manner as to allow certain agreements or settlements which hitherto would have been regarded as collusive.

\section{Condonation}

Section 2 (d) of the Divorce Act provides that condonation "does not include the continuation or resumption of cohabitation during any single period of not more than ninety days, where such cohabitation is continued or resumed with reconciliation as its primary purpose."18 This section would appear to contemplate only a single continuation or resumption of cohabitation with a view to reconciliation and requires that such cohabitation shall not extend beyond ninety days. ${ }^{19}$

It may be noted that section 2 (d) is similar but not identical to section 2 (1) of the Matrimonial Causes Act 1963 (England) ${ }^{20}$ which has been re-enacted in section 42 (2) of the Matrimonial Causes Act 1965 (England). ${ }^{21}$ The efficacy of these sections in promoting reconciliation may well be questioned in light of the decisions in Brown v. Brown ${ }^{22}$ and Herridge v. Herridge ${ }^{23}$ which held that the aforementioned English sections apply to cases where the continuation or resumption of cohabitation is with a view to reconciliation but not to cases where the continuation or resumption of cohabitation is the consequence of reconciliation. Accordingly, the provisions do not create a probationary period during which a wronged spouse who has been reconciled to the wrongdoer can recall his decision. ${ }^{24}$ Although such interpretation of the English provisions threatens to negate their purpose of facilitating re-

18 See also Divorce Act, s. 9(3) (b), infra, n. 60.

10 Compare the Matrimonial Causes Act 1965, Aust. No. 99, s. 10, which would appear to extend to the spouses the right to resume cohabitation with a view to reconciliation on any number of occasions, provided that all such occasions fall within the designated period of three months and do not in aggregate exceed three months in duration when taken in conjunction with the intervals of non-cohabitation ensuing after the first attemped reconclliation. See Matrimonial Causes Act 1965 (Aust.), 8. 10(4). Quaere whether a similar right might not be accorded pursuant to the Canadian Divorce Act s. 2 (d).

See D. J. MacDougail, Proposals To Reform The Law Of Condonation (1965-66), 39 See D. J. MacDougall, Proposals To Reform The Law Of Condonation (1965-66), 39
Aust. L.J. 295, 300, wherein it is suggested that "it would have been preferable to provide that cohabitation at any time after discovery of [the ground for divorce], for a period or periods not exceeding three months in total, will not amount to condonation."

20 Matrimonial Causes Act 1963 (Imp.), 11 and 12 Eliz. 2, c. 45.

21 The Matrimonial Causes Act 1965 (Imp.), 13 \& 14 Eliz. 2, c. 72, s. 42(2), provides as follows:

"42 (2) For the purposes of this Act .... adultery or cruelty shall not be deemed to have been condoned by reason only of a continuation or resumption of cohabitation between the parties for one period not exceeding three months, or of anything done during such cohabitation, if it is proved that cohabitation was continued or resumed, as the case may be, with a view to effecting a reconciliation."

as the case may be, with a view to effecting a reconciliation." Matrimonial Causes Act 1965 (Imp.), s. 1 (2).

22 [1967] P. 105; [1964] 3 W.L.R. 899; [1964] 2 All E.R. 828.

23 [1965] 1 W.L.R. 1506; [1966] 1 All E.R. 93; 109 Sol. J. 814 (C.A.).

24 Id., at 1510 (W.L.R.), wherein Willmer, L. J., stated:

"The section, of course, applies only to a continuation or resumption of cohabitation which takes place with a view to effecting a reconciliation. Where a continuation or resumption takes place in fulfilment of a reconciliation which has already been achleved, the section has no application." 
conciliation between spouses, ${ }^{25}$ the significance of the above judicial rulings is not so substantial in Canada since condonation is an absolute bar to relief in England but only a discretionary bar under section 9 (1) (c) of the Divorce Act of Canada.

\section{Court}

By virtue of the definition of "court" set out in section 2 (e) of the Divorce Act jurisdiction in divorce proceedings is vested in the Supreme Court of the respective Provinces and Territories. The arguments in favour of vesting a concurrent jurisdiction in the County Courts are analysed in the Report of The Special Joint Committee of the Senate and House of Commons on Divorce (Canada), 1967, wherein it is recommended that "the County Courts of all provinces . . . be given jurisdiction in divorce equally and concurrently with the Supreme Courts of the respective provinces." ${ }^{26}$ Briefly stated, the advantages of vesting concurrent or even exclusive divorce jurisdiction in the County Courts relate to (i) the cost of proceedings, and (ii) the accessibility of the court. ${ }^{27}$

It would appear that Parliament's rejection of the above recommendation may lead to inconvenience and hardship with respect to hearings and trials outside of the major cities. For example, where a judge of the Supreme Court is on circuit, difficulties may arise for the litigant by reason of an adjournment of the divorce proceedings ordered pursuant to section 8 (1) of the Divorce Act with the object of affording the parties an opportunity to become reconciled. ${ }^{28}$ Thus, while section 8 (2) provides that after fourteen days have elapsed from the date of any such adjournment, the proceedings shall be resumed on the application of either party, the rights conferred by this sub-section may prove illusory where the judge on circuit has ordered an adjournment but left the district before the expiration of the fourteen days. It is probable that undue delay and expense ensuing from an order of adjournment made pursuant to section 8 (1) will be reduced by the court exercising the statutory power of adjournment before hearing evidence, for in these circumstances the court will not be seised of the issues so as to preclude an application to another judge for resumption of the proceedings. ${ }^{20}$

25 Id., at 1509:

"The Act came into force on July 31, 1963. It is not Irrelevant to observe that by its long title it was described as 'An Act to amend the law relating to matrimonial causes; to facilitate reconciliation in such causes; and for purposes connected with the matters aforesaid."

26 At $36-37$ and $149-151$.

27 See id., at 150-151:

"[The County Courts] have advantages over the Superior Courts for the disposal of local divorce cases. Their procedure is less involved and consequently less costly. County Court judges are resident in County towns and their local offices and officials are readily avallable at all times. The judges can be easily reached when an order needs to be explained or varied and when additional provisions are required. Furthermore, County Court judges are more famillar with the local circumstances and situation. as well as being more accessible, and consequently are in a better position to make helpful judgements. -. Petitioners should be allowed the advantages of trial in the County Courts, not the least being in speed and cost, and readiness and continuity of access."

28 For more detailed analysis of the Divorce Act. s. 8, see infra, sub-heading "Duties of Solicitors and Courts Respecting Reconciliation."

20 See Supreme Court Rules, Part 44, Alberta Divorce Rule 568, which reads as follows: "568 (1) Where, after proceeding to the hearing of evidence, a judge grants an adjournment of the proceedings under sub-section (1) of Section 8 of the Divorce Act, the application for resumption of the proceedings under sub-section (2) of the said section shall be to the same judge.

(2) Where, before proceeding to the hearing of the evidence, a judge grants an adjournment of the proceedings under sub-section (1) of the said section, the 
The vesting of an exclusive divorce jurisdiction in the Supreme Court may also result in hardship with respect to parties who seek the variation or discharge of maintenance orders made in prior divorce proceedings. Section 11 (2) of the Divorce Act provides that a maintenance order made on issue of a decree nisi of divorce may be varied from time to time or rescinded by the court that made the order, and, if this provision is to afford adequate protection to the parties, the accessibility of the court must be assured. Such accessibility, however, would appear somewhat inconsistent with the exercise of exclusive jurisdiction by a judge of the Supreme Court on circuit.

In view of the suggested injustice, inconvenience and undue expense which may arise from the vesting of an exclusive jurisdiction in divorce and corollary proceedings in the Supreme Court, it may well be asked whether the Provinces and Territories in Canada may statutorily confer concurrent jurisdiction in these matters upon the County Courts. In Attorney-General of British Columbia v. McKenzie, ${ }^{30}$ the Supreme Court of Canada upheld the constitutional validity of provincial legislation ${ }^{31}$ which conferred jurisdiction upon the judges of County Courts to try divorce proceedings in their capacity as local judges of the Supreme Court of British Columbia. This decision, however, may be abrogated by virtue of section 2 (e) of the Divorce Act since it was pronounced at a time when the Federal Parliament had not occupied the field of divorce jurisdiction pursuant to the powers conferred under section 101 or section 91 (26) of the British North America. ${ }^{32}$ It is not irrelevant to observe that in giving reasons for the decision in Attorney-General of British Columbia v. McKenzie, Ritchie, J., stated:

The Dominion Parliament has not seen fit to pass any legislation pursuant to its power under s. 101 of the British North America Act, providing for the establishment of courts for the administration of the law of "marriage and divorce" in British Columbia and I am accordingly in agreement ... that it is within the legislative competence of the Legislature of that Province to pass laws relating to the constitution, maintenance and organization of such courts.

While section 2 (e) of the Divorce Act may not be categorized as Federal legislation enacted "pursuant to ... s. 101 of the British North America Act," such legislation is enacted pursuant to section 91 (26). It might therefore be contended that, in accordance with general principle established by judicial authority, occupation of the field of divorce jurisdiction by the Federal Parliament precludes any provincial legislation at least to the extent that such provincial legislation "clashes at the level of law enforcement." legislatures of the respective Provinces and Territories of Canada have no competence to enact legislation conferring a concurrent divorce jurisdiction upon the County Courts, although it is conceivable that provincial legislation which merely confers such jurisdiction upon County Court judges in their capacity as local judges of the Supreme Court would not "clash" with the provisions of section 2 (e) of the Divorce Act which confers jurisdiction upon the Supreme Court.

application for resumption of proceedings under sub-section (2) of the said section shall be:

(a) to the same judge, or

(b) to a judge presiding at the place where such adjournment was granted."

30 [1965] S.C.R. 490 .

31 The Supreme Court Amendment Act, S.B.C. 1964, c. 56.

32 The British North America Act, 1867 (Imp.), 30 Vict., c. 3.

33 Attorney-General of British Columbia v. Smith (1968), 65 D.L.R. (2d) 82,92 (S.C.C.), per Fauteux, J. 


\section{Court of Appeal}

For the purposes of the Divorce Act the term "court of appeal" is defined in section 2 (f) to mean:

(i) with respect to an appeal from a court other than the Divorce Division of the Exchequer Court, the court exercising general appellate jurisdiction with respect to appeals from that court, and

(ii) with respect to an appeal from the Divorce Division of the Exchequer Court, ${ }^{34}$ the Exchequer Court of Canada.

\section{Petition}

Proceedings for the dissolution of marriage are to be instituted under the Divorce Act by a "petition" for divorce, which is defined in section 2 (g) of the Act as meaning "a petition or motion for a decree of divorce, either with or without corollary relief by way of an order under section 10 or 11." It would appear, however, that the required contents of the petition for divorce essentially correspond to those of the Statement of Claim which was formerly used in divorce proceedings in Alberta, although certain additional information is now required for the purpose of implementing the provisions of section 5 (2) of the Divorce Act, which resolve the choice of jurisdiction when spouses have presented competing petitions for divorce in two provinces. ${ }^{35}$

\section{Section 3: Grounds for Divorce-Matrimonial Offences}

Section 3 of the Divorce Act provides that:

3. . . a petition for divorce may be presented to a court by a husband or wife, on the ground that the respondent, since the celebration of the marriage,

(a) has committed adultery;

(b) has been guilty of sodomy, bestiality or rape, or has engaged in a homosexual act;

(c) has gone through a form of marriage with another person; or

(d) has treated the petitioner with physical or mental cruelty of such a kind as to render intolerable the continued cohabitation of the spouses.

\section{Sexual Offences}

It will be observed that the traditional ground for divorce in Canada, namely adultery, has been retained. Sodomy, bestiality and rape now constitute additional grounds for divorce at the instance of an innocent husband or wife ${ }^{36}$ and it is probable that section $3(b)$ does not require in respect of these offences a prior criminal conviction to have been

34 See the Divorce Act, s. 2(e), which vests jurisdiction in divorce for the province of Quebec and Newfoundland in the Divorce Division of the Exchequer Court. See also Divorce Act, ss. 22, 23, discussed infra, sub-heading "Quebec and Newfoundland Courts."

35 See E. I. MacDonald, Divorce Enters The Computer Age (1968), 11 Can. Bar J. 242, 244: " $|A|$ Central Divorce Registry |is| located in Ottawa in which information respecting all petitions for divorce [is to] be registered. The function of the registry office [is] to examine the particulars of every petition for divorce in order to determine whether any prior petition [has] been filed between the parties named in the petition in any other court in Canada and to inform the courts of the results of its examination. . . "Unless comprehensive details in respect of the parties whose names are to be searched are obtained it might appear that a prior petition had been filed by one of the parties whereas, in fact. no such prior petition exists. The statistics required for positive identification have been determined in conjunction with the Dominion Bureau of Statistics, and the various courts [have incorporated], in their new rules of court respecting divorce, requirements that those statistics in their new rules of court

See Alberta Divorce Rule 563 and Form I, supra, n. 29.

For further analysis of the Divorce Act. s. 5 , see infra, subheading "Jurisdiction."

3A Prior to the new Divorce Act, sodomy, bestiality and rape were recognized as grounds for divorce in those Canadian provinces wherein the Divorce and Matrimonial Causes Act 1857 (Imp.), 20 \& 21 Vict., c. 85, applied, but the remedy of divorce was avallable only on the petition of a wife. 
secured. $^{37}$ With respect to the offence of sodomy, it would appear that inter-spousal sodomy may constitute a ground for divorce subject to the discretionary bar of connivance. ${ }^{38}$ Since adultery is a ground for divorce, the offence of rape will presumably be of substantive importance only in the event of a person committing rape on his or her spouse or aiding and abetting another in the commission of rape. ${ }^{39}$

The clause in section 3 (b) which reads "engaged in a homosexual act" is exceedingly vague but it apparently refers to conduct other than sodomy, which constitutes an independent ground for divorce under the section. It is probable that the courts will interpret the clause restrictively and confine it to acts between members of the same sex which involve the surrender of the sexual organs. Since section 3 entitles either a husband or wife to petition for divorce on the ground that the respondent has engaged in a homosexual act, it would appear that the ground is wide enough to include acts of lesbianism. ${ }^{40}$

\section{Bigamy; Polygamy}

The provisions of section 3 (c) of the Divorce Act, whereby a divorce may be obtained on proof that the respondent has, since the celebration of the marriage, gone through a form of marriage with another person, reflect an intention on the part of the Federal Parliament to introduce bigamy as a ground for divorce. ${ }^{41}$ The language of the section, however, is sufficiently broad to permit the party to a monogamous marriage to obtain a divorce where his or her spouse has entered into a subsequent polygamous marriage. Such interpretation of section $3(\mathrm{c})$ is not inconsistent with the decision in Hyde v. Hyde and Woodmansee, ${ }^{42}$ wherein it was held that recognition could not be afforded to a first polygamous marriage for the purpose of granting matrimonial relief.

\section{Matrimonial Cruelty}

Section $3(d)$ of the Divorce Act provides that a petition for divorce may be presented by either spouse on the ground that the respondent has, since the celebration of the marriage, treated the petitioner with physical or mental cruelty of such a kind as to render intolerable the continued cohabitation of the spouses.

In order to appreciate the difficulty which may be encountered in interpreting this provision, it is necessary to advert to the current definitions of cruelty adopted in the Canadian Provinces. Subject to exception in Alberta and Saskatchewan, "cruelty" in relation to mat-

\footnotetext{
37 But quaere whether the use of the term "guilty" in section 3 (b) might not imply the requirement of a prior criminal conviction.

38 T. v. T., [1964] P. 85: 1963] 3 W.L.R. 261; [1963] 2 All E.R. 746: Bampton v. Bampton, [1959] 1 W.L.R. 842; [1959] 2 All E.R. 766; Fast v. Fast, [1945] 3 W.W.R. 66; 61 B.C.R. 503; Statham v. Statham, [1929] P. 131; 98 L.J.P. 113; C. v. C., [1905] 22 T.L.R. 26: and see Divorce Act, s. 9(1) (c). Quaere whether the court will exercise the statutory discretion in favour of a consenting spouse: see T. v. T., wherein the court distinguished between consent and submission to sodomy.

so See $R$. v. Harder, $[1956]$ S.C.R. 489; 114 C.C.C. 129; 4 D.L.R. (2d) 150; $R$. v. Miller, [1954] 2 Q.B. 282; [1954] 2 All E.R. 529; R. v. Clarke (1949), 33 Cr. App. R. 216; R. v. Audley (1631), 3 St. Tr. 401; Hut 115; 1 Hale P.C. 629; 123 E.R. 1140.

Quaere, however, whether the Federal Parliament envisaged the possibility of inter-spousal rape as a ground for divorce. Quaere also whether a woman may be found guilty of rape for the purposes of the Divorce Act.

40 Unnatural or perverted sexual practices by a wife with another woman might also constitute cruelty under the Divorce Act. s. 3(d): see Spicer v. Spicer, [1954] I W.L.R. 1051: [1954] 3 All E.R. 208; 98 Sol. J. 493; Gardner v. Gardner, [1947] W.N. W.L.R. 1051; [1954] 3 All E.R. 208; 98 (1947) 1 All E.R. 630; 63 T.L.R. 417 .

11 See (Dec. 18, 1967) 112 H.C. Deb., no. $103,5580$.

42 (1866), L.R. 1 P. \& D. 130, 35 L.J.P. 57; 14 L.T. 188. See also Lim v. Lim, [1948] I W.W.R. 298, [1948] 2 D.L.R. 353 (B.C.).
} 
rimonial causes has not hitherto been defined by statute but the governing principle which has been applied in Canada ${ }^{43}$ is that established in Russell v. Russell, ${ }^{44}$ wherein it was held that matrimonial cruelty requires proof of acts or conduct that caused "danger to life, limb or health, bodily or mental, or a reasonable apprehension thereof." 4 A broader statutory definition has been enacted in Alberta and Saskatchewan, whereby, for purposes of proceedings for alimony and judicial separation, cruelty includes "conduct that creates a danger to life, limb or health [or] . . . any course of conduct that in the opinion of the court is grossly insulting or intolerable, or is of such a character that the person seeking the separation could not reasonably be expected to be willing to live with the other after he or she has been guilty of such conduct." 46 It is uncertain whether section $3(\mathrm{~d})$ of the Divorce Act implements the Russell v. Russell criterion of cruelty-or whether it projects a wider definition corresponding to the statutory definitions in Alberta and Saskatchewan, and final determination of this issue must necessarily await the decision of the courts. It might be inferred that the statutory phrase "physical and mental cruelty" implies adoption of the Russell v. Russell criterion and that, in order to satisfy the conditions set out in section $3(d)$ of the Divorce Act, it will be necessary to establish two factors, namely:

(i) conduct causing injury to life, limb or health, bodily or mental, or a reasonable apprehension thereof; and

(ii) that such conduct renders further matrimonial cohabitation intolerable. ${ }^{47}$

43 See Diamond v. Diamond (1962), 38 W.W.R. (N.S.) 153 (Man.); Cole v. Cole (1959), 19 D.L.R. (2d) 643 (N.S.); Fralick v. Fralick (1957), 40 M.P.R. 136; 11 D.L.R. (2d) 346 (N.S.) Hutton v. Hutton (1957), 40 M.P.R. 135 (N.S.); Connelly v. Connelly, [1955] 2 D.L.R. 73 (N.S.) Desautels v. Desautels (1954), 11 W.W.R. (N.S.) 142; 62 Man. R. 17; Gilbert v. Gilbert (1947), 21 M.P.R. 76 (N.S.); Jones v. Jones, (1947] 302 (N.S.): McLennan v. McLennan, [1940] S.C.R. 335; [1940] 2 D.L.R. 81 (N.B.) Currey v. Currey (1910), 40 N.B.R. 96. See also Holmes v. Holmes, [1923] 1 W.W.R. 86; [1923] 1 D.L.R. 294; 16 Sask. L.R. 390 (decided before the passing of the statute hereinafter referred to).

44 [1897] A.C. 395; 66 L.J.P. 122 (H.L.).

45 Although this definition is most frequently quoted and applied, it is to be noted that the words "danger to" do not cover precisely the case of the infliction of actual bodily or mental injury. It is accordingly submitted that a more accurate statement. which is supported by Russell v. Russell, id., and later cases, is that bodily hurt, which is supported by Russell v. Russell, id., and later cases, is that bodily hurt, af bodily hurt, or an injury to health, bodily or mental, or a reasonable apprehension thereof, constitutes cruelty: see Power on Divorce, supra, $\mathrm{n}$. 8, at 475 .

40 See The Domestic Relations Act, R.S.A. 1955, c. 89, s. 7(2); Olsen v. Olsen, [1946] 3 W.W.R. 389 (Alta.); Bell v. Bell, [1945] 2 W.W.R. 614 (Alta.); Lovett v. Lovett, [1944] 3 W.W.R. 17, aff'd. at 607 (Alta.). See Queen's Bench Act, R.S.S. 1965, c. 73, s. 25 (3); Herring v. Herring (1963), 41 W.W.R. (N.S.) 400 (Sask.): Rathgeber v. Sathgeber (1954), 13 W.W.R. (N.S.) 232 (Sask.). See also Chrusch v. Chrusch (1967). 62 W.W.R. (N.S.) 471, 477 (Sask.), wherein Sirois, J., stated: "There is no doubt that cruelty in this jurisdiction covers a wider ground than it did in those days in England [i.e., when Russell v. Russell, supra, n. 40, was decided]. However, for cruelty to be any course of conduct that in the opinion of the court is grossly insulting and intolerable, or is of such character that the person seeking judicial separation could not reasonably be expected to live with the other after he or she has been guilty of the same, It seems to me that the course must be grave and welghty, so that it does not appear possible that the duties of must be grave and welghty, so."

47 It is, of course, impossible to categorize acts or conduct as having or lacking the nature and quality which render them capable or incapable in all cases of amounting to legal cruelty. The whole picture of the married life must be considered and each act must be judged in relation to its surrounding circumstances. The physical or act must be mental condition or susceptibilities of the innocent spouse, the intention of the of his or her conduct are all matters which may be decisive in determining on which side of the line a particular act or course of conduct lies: see Chrusch v. Chrusch, supra, n. 46; Gollins v. Gollins, [1964] A.C. 644: [1963] 3 W.L.R. 176: [1963] 2 All E.R. 966 (H.L.); Windeatt v. Windeatt (No. 2), [1962] 2 W.L.R. 1056; Cole v. Cole, supra, n. 43; Jamieson v. Jamieson, [1952] A.C. 525; [1952] 1 T.L.R. 833; [1952] 1 All E.R. 875 (H.L. (Sc.) ). 
Such an inference, however, which follows blindly the judicial definition of cruelty which was established more than seventy years ago in a social, economic and legal environment fundamentally different from that pertaining in Canada today, would, it is submitted, be a retrograde step and inconsistent with the intent of the Federal Parliament ${ }^{48}$ and the philosophy underlying the provisions of the Divorce Act. ${ }^{49}$

"Cruelty" in section $3(d)$ is defined in such a manner as will enable the courts to attach paramount importance to the character and consequences of the conduct complained of rather than to the culpable intention, if any, of the respondent spouse. It has always been recognized that a culpable intention vests any act or conduct with a greater significance but it would appear improper to exalt such intention into a legal prerequisite which would determine in all cases whether conduct is cruel. The essential question which the court should determine under section $3(\mathrm{~d})$ of the Divorce Act is whether the conduct complained of was cruel in that it was sufficiently grave and weighty to say that, from a reasonable person's point of view, after a consideration of any excuse which the respondent might have, the conduct was such that the petitioner ought not to be called upon to endure it. The presence of an intention on the part of the respondent to render matrimonial cohabitation intolerable or proof that the respondent's conduct was "aimed at" the petitioner should not therefore be regarded as an essential element of matrimonial cruelty. To elevate a culpable intention to such status would, it is submitted, undermine the very purpose of section 3 (d) which is not to seek out guilt or punishment but to afford relief from suffering. ${ }^{50}$

In England, it has been held that a decree of divorce on the ground of cruelty is based upon past behaviour and that it is unnecessary for the court to have regard to whether there was a reasonable apprehension of further ill-treatment." It will be observed, however, that section 3 (d) of the Divorce Act requires proof of conduct such as renders intolerable "the continued cohabitation of the spouses." It would accordingly appear that the above holding is inapplicable in Canadian jurisdictions and that a spouse who petitions under section $3(d)$ will be required to prove a need for protection from the threat of future misconduct on the part of the respondent spouse. ${ }^{52}$

48 See (Dec. 19, 1967) 112 H.C. Deb., no. 104, 5600-01.

In presenting evidence to The Special Joint Committee of The Senate and House of Commons on Divorce, the Canadian Bar Association recommended a definition of cruelty which substantially corresponds to the statutory definitions in Alberta and Saskatchewan: Proceedings of The Special Joint Committee, No. 5, Nov. 1, 1967, at 202. See also Minutes of Evidence Taken Before The Royal Commission on Marriage and See also Minutes of Evidence Taken Before The Royal Commission on Marriage and
Divorce (England), 1951-1955, at 30, wherein the General Council of the Bar of England and Wales recommended a corresponding revision of the concept of cruelty. In recommending such revision, the Council stated that it would be undesirable to rigidly adhere to the judicial definition in Russell v. Russell, supra, $n$. 44, because that definition had been established "in a setting of rights, duties, customs and manners which have undergone radical change."

40 See (Dec. 5, 1967) 112 H.C. Deb., no. 94, 5084.

50 See Gollins v. Gollins, supra, n. 47, wherein the respondent's inexcusable conduct. which resulted in impairment of the petitioner's health, was held to constitute cruelty, although the respondent did not wish or intend to injure the petitioner but closed his mind to the consequences of his conduct.

See also Williams v. Williams, |1964] A.C. 698; [1963] 3 W.L.R. 215; [1963] 2 All E.R. 994, wherein the House of Lords ruled that proof of insanity is not necessarily an answer to a charge of cruelty, although the mental derangement of the respondent cannot be wholly disregarded. And see White v. White (1968), 69 D.L.R. (2d) 60 (N.S.).

51 Meacher v. Meacher, [1946] P. 216; 175 L.T. 405; [1946] 2 All E.R. 307 (C.A.). But see Jamieson v. Jamieson, supra, $n$. 47, at 542-46 (A.C.), wherein Lord Merriman strongly criticised the above decision. See also White v. 'White, supra, n. 50 .

52 See Report of The Royal Commission on Marriage and Divorce (England), 1951-1955: (1956) Cmd. 9678, para. 132, wherein it was recommended that in proceedings for 
Section 4: Grounds for Divorce-Permanent Breakdown of Marirage

Section 4(1), paragraphs (a) to (d) of the Divorce Act provide additional grounds for divorce where the husband and wife are living separate and apart and there has been a permanent breakdown of their marriage by reason of the respondent's imprisonment, gross addiction to alcohol or narcotics, disappearance, or incapacity or refusal to consummate the marriage.

\section{Imprisonment}

Section 4(1) (a) permits divorce on proof of a permanent breakdown of marriage resulting from (i) the respondent's imprisonment, pursuant to his conviction for one or more offences, for a period or an aggregate period of not less than three years during the five year period immediately preceding the presentation of the petition; or (ii) the respondent's imprisonment for a period of not less two years immediately preceding the presentation of the petition pursuant to his conviction for an offence for which he was sentenced to death or to imprisonment for a term of ten years or more. ${ }^{53}$

Section 4 (1) (a), sub-paragraph (i) does not require that the divorce be sought while the respondent is in prison and presumably extends a remedy where the respondent has been imprisoned for the designated period but has been released from prison before presentation of the petition for divorce. ${ }^{54}$ Section 4 (1) (a), sub-paragraph (ii), however, specifically requires that the respondent be imprisoned for not less than two years immediately preceding the presentation of the petition and accordingly applies only to cases involving current imprisonment.

\section{Gross Addiction to Alcohol or Narcotics}

Section 4 (1) (b) provides that a petition for divorce may be presented on the ground that there has been a permanent breakdown of marriage by reason that the respondent has, for a period of not less than three years immediately preceding the presentation of the petition, been grossly addicted to alcohol, or to a narcotic as defined in the Narcotic Control Act, and there is no reasonable expectation of the respondent's rehabilitation within a reasonably foreseeable period. There is no definition of the statutory phrases "grossly addicted to alcohol . . . or a narcotic" or "rehabilitation within a reaśonably foreseeable period" and they will accordingly require judicial interpretation. It is probable that the courts will experience considerable difficulty in postulating general criteria as to the meaning of these phrases and that their application must ultimately depend upon the circumstances of the particular case.

As with the other grounds for divorce provided under section 4(1) of the Divorce Act, the parties must be living separate and apart when the petition for divorce is presented. It will be observed, however, that the designated statutory period of three years set out in section 4 (1) (b) refers to the state of gross addiction and not to the fact of separation.

divorce on the ground of cruelty, it should not be necessary for the petitioner to prove that he or she requires protection from the possibility of future injury and

53 All rights of the respondent to appeal the conviction and sentence must have been exhausted: Divorce Act, s. 4 (1) (a) (ii).

s4 The parties must, however, be living separate and apart when the petition for divorce is presented: Divorce Act, s. 4(1). 


\section{Disappearance}

Section 4 (1) (c) provides that a spouse may petition for divorce on the ground that there has been a permanent breakdown of marriage by reason of the respondent's disappearance for a period of not less than three years immediately preceding the presentation of the petition..$^{55}$ This provision is clearly wide enough to include the circumstance of presumed death but is not confined in its operation to such cases.

It would appear that the petitioner must undertake reasonable inquiries and searches to ascertain the whereabouts of the respondent and that a remedy will be available under the section only when all reasonable steps to trace the respondent have been exhausted. ${ }^{s t}$

\section{Non-Consummation of Marriage}

Section 4(1) (d) empowers a spouse to obtain a divorce on proof of the breakdown of marriage resulting from non-consummation of the marriage where the respondent, for a period of not less than one year, has been unable by reason of illness or disability to consummate the marriage, or has refused to consummate it. The right to obtain an annulment of marriage in the Canadian provinces on proof of non-consummation of the marriage by reason of impotence would appear to be preserved by section 26 of the Divorce Act." Accordingly, a choice of remedies, namely divorce or annulment, may, in certain circumstances, now be available where the marriage has broken down by reason of nonconsummation of the marriage resulting from impotence. The provisions of section 4(1) (d) of the Divorce Act do not, however, totally encompass the circumstances wherein the remedy of annulment may be obtained. For example, no remedy is extended under section $4(1)$ (d) to the spouse under the disability but such spouse may have recourse to proceedings for annulment of the marriage. ${ }^{\text {sx }}$ Conversely, the requirement under the law of annulment whereby the disability must be incurable ${ }^{\text {so }}$ would appear irrelevant to the operation of section $4(1)$ (d) of the Divorce Act.

5.5 The Divorce Act, s. 4(1) (c), provides as follows:

"4. . . a petition for divorce may be presented to a court by a husband or wife . . on the ground that there has been a permanent breakdown of their marriage by reason | that | ...

(c) the petitioner, for a period of not less than three years immediately preceding the presentation of the petition, has had no knowledge of or information as to the whereabouts of the respondent and, throughout that period, has been unable to locate the respondent."

56 An obligation of inquiry and search is necessarily to be inferred from the clause in section $4(1)(c)$, id., which reads: "has been unable to locate the respondent."

of See infra, n. 180.

5* An impotent spouse may successfully sue for annulment of marriage on the ground of his or her own disability, provided that he or she did not knowingly deceive the other spouse into contracting the marriage or pursue the proceedings from some imother spouse into contracting the marriage or pursue the proceedings from some im-
proper motive. The petitioner in such a case does not have to prove that the respondent proper motive. The petitioner in such a case does not have to prove that the respondent
repudiated the marriage, but the reaction of the respondent to the situation created by the petitioner's impotence will be taken into account in considering whether the circumstances of the case as a whole are such as to bar the impotent spouse from relief: see Pettit v. Pettit, [1963] P. 177; [1962] 3 W.L.R. 919; [1962] 3 All E.R. 37; Paikin v. Paikin, |1959] O.W.N. 51; Greenlees v. Greenlees, $[1959]$ O.R. 419; $M$. v. M. [1954] 13 W.W.R. (N.S.) 505 (Man.); Harthan v. Harthan, [1949] P. 115; [1949] L.J.R. 115: 11948| 2 All E.R. 639. For earlier decisions requiring the respondent's repudiation of the marriage, see Butti v. Butti, |1937] O.W.N. 18; Davies v. Davies, [1935] P. 58; of the marriage, see Butti v. Butti, $|1937|$ O.W.N. 18; Davies v. Davies, $[1935]$ P. 58; 9 W.W.R. (N.S.) 381 (B.C.).

As to the effect of a pre-marital agreement that the marriage shall be one of companionship only, see Morgan v. Morgan, [1959] P. 92; [1959] 2 W.L.R. 487; [1959] 1 All E.R. 539 and compare Scott v. Scott, |1959] P. 103; [1959] 2 W.L.R. 497; [1959] 1 AII E.R. 531 (respondent's impotence).

50 The impotence must have existed at the time of the marriage and must have continued since then and be permanent. If there is a possibility of effecting a cure by a non-dangerous operation or course of treatment, annulment will not be granted, unless the case is one where the disabled party has unreasonably refused to submit to, or unreasonably persists in postponing, the necessary operation or treatment: see $G$. $v$. 


\section{Living Separate and Apart; Petitioner's Desertion}

The grounds for divorce above considered are supplemented by a broader basis for relief under section 4(1) (e) of the Divorce Act which reads as follows:

4. (1) ... a petition for divorce may be presented to a court by a husband or wife . . . on the ground that there has been a permanent breakdown of their marriage by reason [that] ... .

(e) the spouses have been living separate and apart

(i) for any reason other than that described in sub-paragraph (ii), for a period of not less than three years, or

(ii) by reason of the petitioner's desertion of the respondent, for a period of not less than five years, immediately preceding the presentation of the petition. ${ }^{60}$

Sub-paragraph (ii) of section 4 (1) (e) represents a striking innovation since it specifically recognizes the right of a spouse to petition for divorce where a permanent breakdown of marriage has occurred by reason of his or her own culpable conduct. The provisions of this sub-paragraph will presumably have the effect of reducing the bargaining power of the "innocent" spouse in negotiating the settlement of matters incidental to divorce. It is generally conceded that in jurisdictions wherein matrimonial offences constitute the exclusive basis for dissolution of marriage, the "innocent" spouse may utilize his or her privileged position to secure an unduly advantageous property, maintenance or custody settlement. Although section $4(1)(e)$, sub-paragraph (ii) will not preclude negotiations for settlement between the spouses, it will clearly tend to equalize their bargaining power, and this, it is submitted, is desirable. The possibility of abuse of such power by the "guilty" spouse would appear to be eliminated by the provisions of section $9(1)$, paragraphs (e) and (f) ${ }^{\text {i1 }}$ of the Divorce Act, which presuppose that the court shall be fully informed of any settlement negotiated between the spouses.

It has been observed that a spouse may petition for divorce under section 4(1), paragraphs (a), (b) and (d) of the Divorce Act where a permanent breakdown of marriage has occurred by reason of the respondent's imprisonment, gross addiction to alcohol or a narcotic, or non-consummation of the marriage. Although the aforementioned paragraphs do not themselves provide relief to the spouse thus incapable

G.; [1961] P. 87; [1960] 3 W.L.R. 648; [1960| 3 All E.R. 56; C. v. C. [1949] 1 W.W.R. 911 (Man.); Burton v. Burton, j1945| 3 W.W.R. 1, aff'd. I1945| 3 W.W.R. 765; [1946] 1 D.L.R. 315 (Alta.); B. v. B., $\{1945\}$ W.W.R. 113 (A)ta.); Szrejher v. Szrejher, [1936] O.R. $250 ;$; 1936$] 2$ D.L.R. $413 ;$; . v. A. (1931), 40 O.W.N.' 543 .

As to the operation of the discretionary bar of insincerity in proceedings for annulment of marriage, see Power on Divorce, supra, n. 8, at 206-210. Compare Divorce Act, s. 9(1) (d).

00 For calculation of the period of separation, see Divorce Act, s. 9(3), which reads as follows:

“9. (3) For the purposes of paragraph (e) of subsection (1) of section 4, a period during which a husband and wife have been living separate and apart shall not be considered to have been interrupted or terminated

(a) by reason only that either spouse has become incapable of forming or having an intention to continue to live so separate and apart or of continuing to live so separate and apart of his or her own volition, if it appears to the court that the separation would probably have continued if such spouse had not become so incapable: or

(b) by reason only that there has been a resumption of cohabitation by the spouses during a single period of not more than ninety days with reconciliation as its primary purpose."

The object of paragraph (a) above is to prevent interruption of the period of separation or desertion arising from supervening circumstances such as insanity. With respect to paragraph (b) it will be observed that, in calculating the duration of the period of separation or desertion under section $4(1)(e)$, the period of not more than ninety days during which the parties cohabit with a view to reconciliation is to be included.

61 For discussion of these provisions, see infra, subheadings "Bars to Relief under Section 4(1) (e)" and "Protection of Children." 
of discharging his matrimonial obligations, such spouse may presumably petition for divorce pursuant to the provisions of section 4 (1) (e) subparagraph (ii)..$^{62}$

A broad interpretation of the provisions of sub-paragraph (i) of section 4 (1) (e) of the Divorce Act would suggest that where there has been a permanent breakdown of the marriage by reason of the spouses having lived separately for three years immediately preceding the presentation of the petition for divorce, the circumstances or causes leading to the separation are irrelevant provided that they are not such as fall within the ambit of sub-paragraph (ii) of section 4 (1) (e) and do not give rise to the operation of the statutory bar to relief set out in sections 9 (i) (f) of the Act. It would thus appear that sub-paragraph (i) may provide the right to divorce where the petitioner has been deserted by the respondent, or where separation occurred by consent of the parties, or pursuant to an order for judicial separation, ${ }^{63}$ or as a consequence of an illness, whether physical or mental, which resulted in the incarceration of the disabled spouse. ${ }^{04}$ It is possible, however, that cases falling within this last category may be excluded by the courts interpreting the clause "living separate and apart" to require proof of an animus separandi in addition to the factum of separation. It is not, perhaps, irrelevant to observe that such an interpretation has been adopted by Australian courts in their application of similar, but not identical, statutory provisions. ${ }^{65}$ In Macrae v. Macrae, ${ }^{616}$ Heron, C.J., stated:

In Crabtree v. Crabtree [(1963), 5 F.L.R. 307; 64 S.R. (N.S.W.) 110] the Full

Court of the Supreme Court of New South Wales held that husband and wife living under one roof may yet be living separately and apart within the meaning of $s .28(\mathrm{~m})$ of the Matrimonial Causes Act 1959. That was the precise decision reached, but the meaning of the expression 'separately and apart' was considered and discussed together with the decision in Main v. Main [(1949), 78 C.L.R. 636], a decision of the High Court on the Western Australian Act of 1945. In the joint judgment of Sugarman, J., and Dovey, J., in the former case the opinion was expressed that the phrase 'separately and apart' should be given the meaning in the field of separation as a ground of divorce as they have been in relation to desertion. In the joint judgment the following passage appears: "Although in the ordinary usage of speech a reference to living "separately and apart" might not be regarded as appropriate to residence under the same roof, those words have not been excluded from this application in matrimonial law, and they, or one or other of them, have often been used in judgments of the courts as applying to this situation. As they are thus used in relation to desertion, it is difficult at first sight to appreciate why they should not have a similar meaning in the related field of separation as a ground of divorce. It is true that desertion, as a ground, rests on the familiar principle of matrimonial fault, whereas the principle on which separation has been accepted as a ground for dissolution is the relatively novel one in this country

62 Quaere whether such spouse might petition under section 4 (1) (e)(i) if his or her disability precluded an animus deserendi. This may depend upon whether the courts interpret "living separate and apart" to require proof of an animus separandi: see infra, text, at $n$. 65 et seq.

As to the power of the court to deny relief sought under section $4(1)$ (e), subparagraphs (i) and (ii), see Divorce Act, s. 9(1) (f). discussed infra, sub-heading paragraphs (i) and (ii), see Divorce ".

63 Specific provisions have been enacted in Australia and New Zealand, whereby separation pursuant to a judicial order constitutes a ground for divorce: see Matrimonial Causes Act 1959, supra, n. 13, ss. $28(\mathrm{~m}), 36(2)$ (separation for five years); Matrimonial Proceedings Act 1963, supra, n. 2, s. 21 (n) (separation for three years).

64 In Australia and New Zealand, the insanity of the respondent constitutes an independent ground for divorce; see Matrimonial Causes Act 1959, supra, n. 13, ss. 28(1), 35; Matrimonial Proceedings Act 1963, supra, n. 2, s. 21(1).

65 The Matrimonial Causes Act 1959, supra, n. 13, s. $28(\mathrm{~m})$, reads as follows:

"28. the marriage may be based on [the ground]...

(m) that the parties to the marriage have separated and thereafter have lived separately and apart for a continuous period of not less than five years immediately preceding the date of the petition, and there is no likelihood of cohabitation being resumed."

oo (1967), 9 F.L.R. 441, 447-448; 86 W.N. 121, 126-127. 
of a breaking-down of the marriage reiationship. But, for purposes here relevant, this seems to point to a difference in practical application rather than in principle. Each ground requires a combination of factum and animus such as must be difficult to establish, and whose existence requires to be examined into with great caution, where the parties have continued to live under the same roof. But if, as is now established, these considerations are not to be regarded as a necessarily insuperable bar in the one case, it is difficult to understand why they should be so regarded in the other. In this reference we are required to construe the words "live separately and apart" as used in the Matrimonial Causes Act 1959 (Cth) and it is a reasonable assumption that Parliament intended them to bear the sense which had become a familiar one in matrimonial law. Moreover, although the ground of separation is a novel one, there is an association between it and the ground of desertion in the scheme of the Commonwealth Act which is opposed to the view that they are intended to be governed, in respect here relevant, by different principles'.

The decision of the Full Court, Nagle J. concurring, was that each ground requires a determination of factum and animus and that Parliament intended the words 'live separately and apart' to bear the sense in $s$. $28(\mathrm{~m})$ as it did in matrimonial law generally.

... In light of the decision in Main v. Main the true rule is that physical separation and the destruction of the consortium vitae or matrimonial relationship are each involved in $\mathrm{s} .28(\mathrm{~m}) .6$

The conclusion that the words "separate and apart" in sub-paragraph (i) of section 4 (1) (e) were intended to import the negation of the matrimonial relationship and therefore require proof of an animus separandi and the factum of separation would appear to be strengthened by the language of section 9(1) (d) of the Act which provides that no decree shall be issued "if there is a reasonable expectation that cohabitation will occur or be resumed within a reasonably foreseeable period." "is It is doubtful, however, whether the factum of separation must occur by mutual volition of the spouses. It would appear that where separation occurs by force of circumstance, as, for example, by confinement of a spouse in a mental institution or assignment of a spouse on military service abroad, such spouse is entitled to proceed for divorce pursuant to section $4(1)$ (e), sub-paragraph (i), if his or her marriage partner has abandoned the matrimonial relationship during such enforced separation and thus caused the permanent breakdown of the marriage. A more difficult question to resolve is whether the spouse who voluntarily abandons his or her matrimonial obligations in the above circumstances may also seek relief under the same sub-paragraph on the basis that his or her withdrawal from the matrimonial consortium was a justifiable consequence of the enforced separation such as would negate any finding of desertion, which would require recourse under section 4 (1) (e), sub-paragraph (ii)..$^{69}$ It is submitted that the granting of relief under

67 See also Collins v. Collins (1961), 3 F.L.R. 17, wherein it was held that the absence of the husband in hospital for a substantial period during which the wife visited him and discharged other matrimonial obligations was inconsistent with termination of the matrimonial consortium and not separation within the meaning of the Matrimonial Causes Act 1959, supra, n. 13. But compare Koufalakis v. Koufalakis, [1964] A.L.R. 196; 4 F.L.R. 310 wherein separation brought about by the act of the petitioner in having the respondent confined in a mental institution and afterwards petitioner in having the respondent confined in a mental institution and after
sent abroad was held to satisfy the provisions of the aforementioned statute.

For the interpretation accorded by Canadian courts to the clause "living separate and apart" in the Divorce Jurisdiction Act, R.S.C. 1952, c. 84. s. 2 (now repealed), see Schiach v. Schiach and Poulter (No. 2), |1940| 3 W.W.R. 57; |1941| 1 D.L.R. 263 (Sask. C.A.). See also J.B. v. A.W.B., |1958\} O.R. 281: 13 D.L.R. (2d) 218, wherein it was held that a finding of desertion may be made where the parties are residing under the same roof, provided that the household has ceased to be in substance one household or one home.

i8 See also Divorce Act, s. 9(3), quoted supra, n. 60, which may imply that an animus separandi at the commencement of the designated statutory period is a prerequisite to a finding that the spouses have been living separate and apart within the meaning of section $4(\mathrm{e})$ (i). This section may also imply that the separation must originate by volition of at least one of the spouses: see infra, text.

69 See P. E. Nygh, Living "Separate and Apart" As a Ground for Dissolution of Marriage in Australia (1966), 6 J. Fam. Law 219, 221-222: 
sub-paragraph (i) in this latter case would not be inconsistent with the language of $^{70}$ or the policy underlying ${ }^{71}$ the sub-paragraph, which appears to be directed to legal recognition of the fact of permanent breakdown of marriage rather than to an analysis of the causes of or circumstances attendant upon the breakdown. ${ }^{72}$

\section{Bars to Relief under Section 4 (1) (e)}

Section $9(1)(f)$ of the Divorce Act provides that, where a decree of divorce is sought under section 4 (1) (e) of the Act, it shall be the duty of the court to refuse the decree if the granting of it would be unduly harsh or unjust to either spouse or would prejudically affect the making of reasonable arrangements for the maintenance of either spouse. This provision is similar but not identical to section 37, subsections (1) and (2) of the Matrimonial Causes Act 1959 (Australia), ${ }^{73}$ and accordingly some guidance as to the interpretation to be accorded to the provision may be found in decisions of the Australian courts. In applying section 37 (1) of the Matrimonial Causes Act 1959 (Australia) it has been held that the phrase "harsh and oppressive" 4 presupposes a substantial detriment resulting from the granting of a decree and generalities such as the real or imagined stigma of divorce or the mere loss of the marriage status are not embraced by the phrase. Thus, in McDonald

"It is clear that .. . the separation need not be voluntary on both sides, l.e., by mutual consent. isee Matrimonial Causes Act 1959, supra, n. 13, s. 36(1).]. . . independently of the parties' control such as by incurable disease of mind or body or lengthy imprisonment. In America the prevalling attitude appears to be that the break must be due to the volition of at least one of the spouses. In Australla the position is not quite as clear.

In Main v. Main I(1949), 78 C.L.R. 636 decided under a 1945 enactment in Western Australla], the High Court of Australla held that a wife could obtain a divorce on the ground of separation where her husband had been confined . . . in a hospital for the incurably ill. .. [Since the enactment of the Matrimonial Causes Act 1959, however,] Justice Crisp in the Tasmanian case of Collins v. Collins [supra, n. 67] has held that the hospitalization of the husband did not set the period of separation running. On the other hand Justice Travers in South Australia has held that a wife, running. On the other hand Justice Travers in South Australia has held that a wife,
in being committed to an asylum, had separated from her husband. [Koufalakis v. Koufalakis, suyra, n. 67.]"

It is submitted that the decislons in Collins v. Collins and Koufalakis v. Koufalakts are reconcilable by reason that the former case involved only partial impairment of the matrimonial consortium whereas the latter involved total destruction of the matrimonial consortium: see supra, $n$. 67. Moreover, since the decision in Collins $v$. Collins focussed upon the need to establish total cessation of the matrimonial relationship, it may be regarded as less than authoritative on the issue of whether relationship, it may be regarded as less than authoritath

to Section 4(1) (e) (1) explicitly applies where the spouses have been living separate and apart "for any reason other than that described in subparagraph (ii)." that is, for any reason other than "the petitioner's desertion of the respondent."

71 See Proceedings of The Standing Committee on Banking and Commerce (The Senate of Canada). No. 23, Jan. 31, 1968 and Feb. 1, 1968, at 196 and 201.

72 But see Divorce Act, s. 9(1) (f), discussed infra, sub-heading "Bars to Relief under Section $4(1)(e)$." Presumably, the court might conclude that it would be "unduly harsh and unjust" to grant a divorce decree sought under section 4(1) (e) if the cause of the separation and consequent marriage breakdown was the physical or mental ill-health of a spouse and the granting of the decree would be likely to aggravate this condition. Compare Bailey v. Bailey, [1964] A.L.R. 370; (1962), 3 F.L.R. 476.

73 The Matrimonial Causes Act 1959, supra, n. 13, s. 37 (1) (2) read as follows:

"37. (1). Where, on the hearing of a petition for a decree of dissolution of marriage on the ground specified in paragraph $(m)$ of section 28 of this Act (in this section referred to as 'the ground of separation'), the court is satisfied that. by reason of the conduct of the petitioner. whether before or after the separation commenced, or for any other reason. It would, in the particular circumstances of the case, be harsh and oppressive to the respondent, or contrary to the public interest, to grant a decree on that ground on the petition of the petitioner, the court shall refuse to make the decree sought.

"(2). Where, in proceedings for a decree of dissolution of marriage on the ground of separation, the court is of opinion that it is just and proper in the circumstances of the case that the petitioner should make provision for the maintenance of the respondent or should make any other provision for the benefit of the respondent, whether by way of settlement of property or otherwise, the court shall not make a decree on that ground in favour of the petitioner until the petitioner has made a decree on that ground in favour of the petitioner until the petitioner has made arrangements to the satisfaction of the court

74 Compare the phrase "harsh and unjust" in the new Canadian Divorce Act, $8.9(1)(f)$. 
v. McDonald, ${ }^{75}$ Herrin, C.J., stated:

Each of the two words in the phrase 'harsh and oppressive' must be given its meaning. The test of harshness and oppressiveness is subjective and must relate to the respondent. What is envisaged is not some such concept in the abstract or as applying generally to others, or even to the reasonable man or woman. The phrase connotes some substantial detriment to the party before the court. It is not satisfied by argument based on generalities or on social philosophy or that the petitioner is at fault or by suggested injustice, e.g. loss of status or such as would be said to result from unsuccessful opposition by the respondent. ${ }^{78}$

It has also been held that the granting of a decree will not ordinarily be deemed "harsh and oppressive" merely by reason of the respondent's conscientious or religious objections to divorce. The most recent pronouncement on this issue appears in Macrae v. Macrae ${ }^{7 \pi}$ wherein Sugarman, J.A., observed:

Opposition to divorce on religious grounds as a ground for treating the granting of a decree under $\mathrm{s}$. $28(\mathrm{~m})$ as 'harsh and oppressive' has been the subject of consideration in the courts of several States-see Judd v. Judd; ${ }^{\mathbf{7}}$ Painter v. Painter; ${ }^{70}$ Lamrock v. Lamrock;80 Kearns v. Kearns; ${ }^{81}$ McDonald v. McDonald.$^{82}$ These are decisions each on its own particular circumstance, but certain guiding lines may be said to appear from them. These are that, although there might be special cases in which the overriding of a religious objection could amount to harshness and oppressiveness (Lamrock v. Lamrock), this is not so in general (Painter v. Painter; Kearns v. Kearns; McDonald v. McDonald), but the religious objection may be a fact to be taken into account with other circumstances (Judd v. Judd; Painter v. Painter; Kearns v. Kearns).

In my opinion the mere circumstance that a respondent feels constrained on religious or any other grounds to reject the advantages which, in the public interest, the legislature offers to him or her, to oppose the suit because of an objection to the institution of divorce, and to continue to treat himself or herself as married to the petitioner notwithstanding the dissolution of the marriage, does not of itself make the granting of a decree harsh and oppressive. To conclude otherwise would be, not to have regard to 'the particular circumstances of the case' but to reduce the scope of the ground of separation under section $28(\mathrm{~m})$ by reference to a general argument which might be advanced against sanctioning dissolution on such a ground. This argument was no doubt considered and overruled before the ground was placed on the statute-book.

It is possible that the phrase "harsh and unjust" in section $9(1)$ ( $f$ ) of the Divorce Act will be narrowly construed and that its application will be found primarily in the context where financial hardship would ensue as a consequence of the granting of a divorce decree. Although section 9 (1) (f) expressly provides that a decree shall be refused "if the granting of the decree would ... prejudicially affect the making of . . . reasonable arrangements for the maintenance of either spouse," this provision does not protect a financially dependent spouse where the petitioner's condition is such as to preclude the provision of maintenance or other financial benefits for the respondent. ${ }^{83}$ In these circumstances, it might be concluded that the granting of a divorce decree would be "harsh and unjust," if the respondent would be thereby deprived of pension or insurance benefits, dower, or of rights that might otherwise accrue under

75 (1964), 64 S.R. (N.S.W.) 435, 450; 81 W.N. (Pt. 2) 336.

70 See also Macrae v. Macrae, supra, n. 66, at 465 (F.L.R.) and 141 (W.N.), wherein Walsh. J.A., stated that ". . there should be something in the particular case which goes beyond the normal, and indeed inevitable, consequences of the granting of a decree. . . ."

77 See id., at $460-461$ and $137-138$.

78 (1961), 3 F.L.R. 207, 211.

79 (1962); 3 F.L.R. 370, 375-376; 4 F.L.R. 216, 220.

80 (1963), 4 F.L.R. 81, 84.

81 (1963), 4 F.L.R. 394, 402.

82 Supra, n. 75, at 451, 456, 464 (S.R. (N.S.W.))

83 In such a case, "the making of reasonable arrangements for the maintenance of the [respondent]" would be prejudiced not by "the granting of the decree" but by reason of the impecunious condition of the petitioner. 
family inheritance legislation. ${ }^{* 4}$ A more difficult question to resolve is whether the granting of a decree would be harsh and unjust where the petitioner intends to remarry and such remarriage would reduce his or her capacity to support the respondent. In Kearns v. Kearns, ${ }^{85}$ Hart, J., stated:

In nearly all cases, except where the petitioner is very wealthy, if a decree under $s .28(m)$ is made and there is provision for maintenance, there will be a risk that the respondent will suffer some diminution of security. It could not possibly be the intention of Parliament in introducing this Act that only wealthy people should get divorces under $\mathrm{s} .28(\mathrm{~m})$.

But in Penny v. Penny (No. 2) ${ }^{80}$ it was held that a husband, who was unable to discharge his obligations under maintenance orders made in favour of the respondent and a former wife, should be denied a decree of divorce sought under section $28(\mathrm{~m})$ with a view to entering a third marriage, since the granting of the decree would result in further reducing his ability to discharge such obligations and would therefore be harsh and oppressive to the respondent.

\section{Presumption of Marriage Breakdown}

To satisfy the requirements of section $4(1)$ of the Divorce Act it is necessary to establish (i) that there has been a permanent breakdown of the marriage and (ii) that such breakdown occurred by reason of one or more of the circumstances designated in paragraphs (a) to (e).$^{87}$ By virtue of section 4(2) of the Act, proof of any of the circumstances designated in the aforementioned paragraphs will require the court to presume a permanent breakdown of the marriage. ${ }^{88}$ Such presumption, however, would appear to be provisional and not conclusive since the imposition of a conclusive presumption under section 4 (2) would necessarily negate all reference to permanent breakdown of marriage in section 4 (1) and render the circumstances designated in paragraphs (a) to (e) of this subsection grounds for divorce in their own right, and it is reasonable to infer that this was not the intention of the Federal Parliament. Some guidance in the interpretation of section 4 (2) may be found in Gray v. Kerslake, ${ }^{89}$ wherein Cartwright, J., stated:

The question of the meaning to be given to the word 'deemed' when used in a statute has been considered in many decisions. . . . As is pointed out by Meredith C.J.C.P. [in Hickey v. Stalker'0] the word may mean 'deemed conclusively' or 'deemed until the contrary is proved'.

... Middleton J., as he then was, after referring to the treatment of the word in the dictionaries, continued: 01

'Far more important are two decisions of the Supreme Court of Nova Scotia. In Regina v. Freeman (1890), 22 N.S.R. 506 Townshend J., speaking for the

\footnotetext{
84 See Ferguson v. Ferguson, [1965] A.L.R. 310; (1964), 6 F.L.R. 31.

85 Supra, n. 81, at 402 .

86 (1966), 8 F.L.R. 128.

87 The Divorce Act, s. 4(1) reads:

T4. (1) ... a petition for divorce may be presented to a court by a husband or wife where the husband and wife are living separate and apart, on the ground that there has been a permanent breakdown of their marriage by reason of one or more of the following circumstances. ....

The circumstances thereafter designated include (a) the respondent's imprisonment;

(b) the respondent's gross addiction to alcohol or narcotic; (c) the respondent's disappearance; (d) the respondent's inability or refusal to consummate the marriage: and (e) the spouses having lived separate and apart for a specified number of and (e) the spouses having lived separate

88 The Divorce Act, s. 4(2), reads as follows:

"4. (2) On any petition presented under this section, where the existence of any of the circumstances described in subsection (1) has been established, a permanent breakdown of the marriage by reason of those circumstances shall be deemed to have been established."

80 (1957), 11 D.L.R. (2d) 225, 239-240.

90 [1924] 1 D.L.R. 440, 442; 53 O.L.R. 414, 416.

91 Id., at $444-445$ and $418-419$.
} 
full Court, says at p. 513: "The word 'deemed' has acquired no technical or peculiar signification when used in legislation, but, like other words, must be interpreted with reference to the whole Act of which it forms a part."

In the second case, Rex v. Fraser (1911), 45 N.S.R. 218, the statute provided that an act which in itself might be lawful or might be unlawful "shall be deemed" to have been unlawful; it was argued that this meant "held conclusively" or "adjudged and determined." The same learned judge, then Sir Charles Townshend, C.J., says at p. 220: "I should be sorry to believe that our Legislature was capable of enacting such an unreasonable law, and I am quite confident the Legislature never contemplated anything so contrary to natural justice:" and so he concludes that the true meaning to be given to the word "deemed"... is that it shall be treated as "prima facie evidence", "held until the contrary is proved."

... 'I think that this modified meaning should be given to the word as found in our statute, for it will not only save the legislation from being unjust but also from being absurd. That it is the duty of the Court, in seeking the true legislative intention of an Act, ... to regard the possible consequences of alternative constructions of ambiguous expressions, has been determined in many cases.'

In the case at bar, and in many cases which can easily be imagined, to construe the word 'deemed'. . . as 'held conclusively' would be to impute to the Legislature the intention .. . of requiring the Court to hold to be the fact something directly contrary to the true fact. ... This result can, and in my opinion should, be avoided by construing the word to mean 'deemed until the contrary is proved'.

\section{Jurisdiction ${ }^{92}$}

Section 5(1) of the Divorce Act provides that the court of any province has jurisdiction in divorce if the petitioner is domiciled in Canada and either the petitioner or respondent has been ordinarily resident in the province for a period of at least one year immediately preceding the presentation of the petition and has actually resided in the province for at least ten months of that period. This provision reflects a fundamental change from the previous basis of jurisdiction which required proof of domicile within the province wherein proceedings were instituted. Its significance becomes even greater when the subsection is read together with section $6(1)$ which, for purposes of divorce jurisdiction, recognizes the capacity of a married woman to acquire a domicile independent of that of her husband. ${ }^{93}$ Some uncertainty will inevitably exist as to the meaning of the phrase "ordinarily resident" but aid in interpreting the phrase may be obtained from the decision in Stranski v. Stranski, ${ }^{94}$ wherein it was held that absences from the jurisdiction, whether on business or for pleasure, would not necessarily break the period of ordinary residence. In delivering judgment in this case, Karminski, J., stated:

Clearly, mere temporary absences ..., such as a holiday abroad, would not make a gap in the period of ordinary residence. Nor, in my view, would a longer gap of some months, such as one caused by a journey overseas ... on a business trip, necessarily break the period of ordinary residence. ${ }^{95}$

92 See D. Mendes Da Costa, Some Comemnts on The Conflict of Laws Provisions of The Divorce Act, 1968 (1968), 46 Can. Bar Rev. 252.

03 The Divorce Act, $s$. $6(1)$, reads as follows:

"6. (1) For all purposes of establishing the jurisdiction of a court to grant a decree of divorce under this Act, the domicile of a married woman shall be determined as if she were unmarried and, if she is a minor, as if she had attained her majority." as if she were unmarried and, if she is a minor, as if she had attained her majority." a domicile of choice and that his domicile will continue to depend upon that of a domicile of choice and that his domicile will continue to depend upon that of criticism of this decision see S. Prevezer, Divorce in the English Concept of Laws (1954), 7 Current Legal Problems 114, 121-123.

04 [1954] P. 428, 437; [1954] 3 W.L.R. 123; [1954] 2 All E.R. 536.

95 But quaere whether such absences are also consistent with a finding that the parties "have actually resided" in the province in accordance with the requirements of the Divorce Act, s. 5(1).

See also Thomson v. Minister of National Revenue, [1946] S.C.R. 209, 224, wherein Rand, J., stated: "The expression 'ordinarily resident' carries a restricted signification, 
To avoid possible difficulties arising from the joint operation of sections $5(1)$ and $6(1)$ which might result in the spouses presenting competing petitions for divorce in two provinces, section $5(2)$ provides that, where petitions are pending before two courts that would otherwise have jurisdiction under the Act, the court to which a petition is first presented has exclusive jurisdiction to grant relief between the parties and if the petitions are presented on the same day, the Divorce Division of the Exchequer Court has exclusive jurisdiciton. ${ }^{96}$ It is questionable whether this subsection adequately solves the problem of conflicting petitions and it might well have been better to leave a general discretion in the courts to determine the most convenient forum.97

Section $5(3)$ provides that

5. (3) Where a husband or wife opposes a petition for divorce, the court may grant to such spouse the relief that might have been granted to him or her if he or she had presented a petition to the court seeking that relief and the court had had jurisdiction to entertain the petition under this Act.

It would thus appear that, where a petition is opposed, the court may assume jurisdiction to grant relief to the respondent spouse, notwithstanding that such spouse fails to satisfy the jurisdictional requirements of section $5(1)$. In other words, if jurisdiction vests in respect of the petitioner's claim, a derivative jurisdiction will extend in respect of the respondent's counter-petition.

\section{Recognition of Foreign Decrees}

Section 6(2) of the Divorce Act expressly preserves the common law rules regulating the recognition of foreign divorce decrees and further provides that recognition shall be given to a decree of divorce granted by a foreign court or tribunal that exercised jurisdiction on the basis of the wife's separate domicile in that foreign country. ${ }^{08}$ This statutory extension of the common law rules is a corollary to sections 5 (1) and 6 (1) which empower a Canadian court to exercise jurisdiction in divorce on the basis of the wife's separate domicile. But as one writer has observed "section 6(2) will . . . be rendered of diminished importance, if not otiose" ${ }^{\text {90 }}$ if the Canadian courts adopt the reasoning of the House of Lords in Indyka v. Indyka, ${ }^{100}$ wherein it was suggested that the criterion for recognition at common law should depend upon the existence of a substantial connection betwen the petitioner and the foreign country or territory exercising jurisdiction.

and although the first impression seems to be that of preponderance in time, the decisions [in England] reject that view. It is held to mean residence in the course of the customary mode of life of the person concerned, and is contrasted with special or occasional or casual residence. The general mode of life is, therefore, relevant to a question of its application."

96 See supra, contents of $\mathbf{n} .35$.

o7 Compare Matrimonial Causes Act 1959, supra, n. 13, s. 26(1),(2) which reads as follows:

"26. (1) Where it appears to a court in which a matrimonial cause has been instituted under this Act that a matrimonial cause between the parties to the marriage... has been instituted in another court having jurisdiction under this Act, the court may, in its discretion stay the cause for such time as it thinks fit.

(2) Where it appears to a court in which a matrimonial cause has been instituted (2) Where it appears to a court in which a matrimonial cause has been instituted subsection applies) that it is in the interests of justice that the cause be dealt with in another court having jurisdiction to hear and determine that cause, the court may transfer the cause to the other court."

98 For detailed analysis of section 6(2) see D. Mendes Da Costa, loc. cit. supra, n. 92, at $289-91$.

09 Id., at 289-290.

100 [1967] 3 W.L.R. 510; [1967] 2 All E.R. 689; III Sol. J. 456. 


\section{Duties of Solicitors and Courts Respecting Reconciliation ${ }^{101}$}

Section 7 imposes a duty on barristers and solicitors to advise every divorce client of the reconciliation provisions of the Divorce Act, to inform the client of known marriage counselling or guidance facilities available, and to discuss with the client the possibility of reconciliation with his or her spouse. ${ }^{102}$ It is also the duty of the barrister or solicitor to certify on any petition for divorce that he or she has duly discharged the above obligations. ${ }^{103}$ Commenting upon the value and effect of such requirements as are set out in section 7, the Law Commission in England has stated:

Marriage Guidance Councils are unanimous in saying that their chances of success are greatest if their help is sought at an early stage in disputes between husband and wife. Their chances are greatly diminished by the time that either party has resorted to legal advice, and have dwindled almost, but not quite, to vanishing point by the time that a petition is filed. . . .

Nevertheless, we do think it very desirable that couples in matrimonial difficulties should be encouraged to resort to marriage guidance agencies and that they should be in a position to find out with ease what guidance facilities are available. Solicitors are among the people from whom advice may be sought at an early stage of the matrimonial differences and, though in practice they are very conscious of their duty to assist in a possible reconciliation, they are not trained in the art of marriage conciliation and can normally only pass their clients on to those who are. It is therefore very important that they should have at their finger tips details of the various marriage guidance agencies. Accordingly, we are attracted by the provisions of rule 15 of the Matrimonial Causes Rules of the Comomnwealth of Australia, whereby when a matrimonial petition is filed the solicitor ... must certify, inter alia, that he has brought the names of available marriage guidance organizations to the attention of his client and has discussed with him the possibility of a reconciliation being effected, either with or without the assistance of such an organization. We suggest that consideration should be given to the introduction of a similar rule in England. We think that its value is not so much that a reconciliation is likely to be effected at that late stage of the matrimonial differences, but rather that it ensures all solicitors have ready to hand a list of marriage guidance organizations, so that this can be given to those clients who consult them at an earlier stage. We are informed that in the year ending June 1964, seven per cent of all cases dealt with by approved marriage guidance organizations in Australia were referred to them by legal practitioners, and that many of these references are thought to be due to the existence of the rule quoted.104

A further provision of the Divorce Act aimed at promoting reconciliation between the spouses, is section $8(1)$, which requires the court, before proceeding to the hearing of evidence, to direct such inquiries to the petitioner and, where the respondent is present, to the respondent as the court deems necessary in order to ascertain whether a possibility exists of matrimonial reconciliation. This subsection also provides that if at that time or any later time in the proceedings it appears to the court that there is a possibiilty of such reconciliation, the court shall adjourn the proceedings to afford the parties an opportunity of becoming reconciled, and, with the consent of the parties or in the discretion of the court, nominate a person to endeavour to assist the parties with a view to their possible reconciliation. Section $8(2)$ provides that where fourteen days have elapsed from the date of any adjournment so ordered and either of the parties applies to the court to have the proceedings resumed, the court shall resume the proceedings. ${ }^{105}$

\footnotetext{
101 See infra, sub-heading "Admissions and Communications Made in Course of Attempted Reconciliation."

102 Divorce Act, s. 7(1)

103 Id., s. 7 (2).

104 The Law Commission (England), Reform of The Grounds Of Divorce: The Field Of Choice (1966) Cmnd. 3123, paras. 30-31.

100 See supra, text to and contents of n. 29.
} 
The efficacy of section 8 in promoting reconciliation between spouses may prove to be less than substantial and, if the practice adopted in Australia is followed in Canada, the occasions upon which an adjournment will be ordered will be few. In an analysis of the statutory provisions in Australia which correspond to section 8 of the Divorce Act D. M. Selby, Judge in Divorce of the Supreme Court of New South Wales, has observed:

Experience suggests that the provisions . . remain in the realm of pious hope. By the time a matrimonial cause reaches a hearing the parties are too far apart, one of them, at least, is too anxious for a final determination of the suit and too much bitterness has been engendered to allow any reasonable prospect of reconciliation. It is only on the rarest occasions that attempts are made . . . to effect a reconciliation after the hearing has begun, and it is doubtful if any such attempt has been successful. 106

It may, nevertheless, be contended that such provisions serve a useful purpose. This contention was recently endorsed by the Law Commission in England which stated:

... Both in Australia and New Zealand there is always power to adjourn the proceedings (but not to dismiss the petition) to enable the possibility of reconciliation to be explored and to refer the parties to a conciliator. We are informed that in Australia, where this power has existed since 1961, only fifteen cases were recorded up to the end of 1965 in which this procedure was adopted and that reconciliations were effected in only two of these cases. This confirms our view that divorce proceedings are very rarely brought unless the marriage has irretrievably broken down, and that attempts to mend it once litigation has begun are unlikely to be successful. Nevertheless, so long as the power is sparingly exercised (as it obviously has been in Australia), we think that the power to adjourn (not to dismiss) the petition should be available. The saving even of a very small number of marriages is worthwhile, provided that it is not accompanied by a disproportionate waste of time and effort in a great many others. Accordingly, . . . we suggest that the court should be expressly empowered to adjourn, for a limited period, to enable the possibility of a reconciliation to be explored. ${ }^{107}$

It would appear somewhat misleading to evaluate the potential benefits of the aforementioned statutory provisions merely by reference to their limited implementation by the courts and the relatively small number of matrimonial reconciliations achieved thereunder. Indeed, the primary benefit possibly resulting from a more extensive use of the stautory conciliation procedures might be that counselling of the spouses will assist them in mutually and consensually resolving issues incidental to the divorce proceedings, such as custody of children, visitation rights, disposition of matrimonial assets and obligations of support, since these matters might well be resolved as a by-product of an unsuccessful reconciliation conference without the bitterness and rancour ordinarily associated with the more traditional adversary procedure.

\section{Additional Duties of Court; Bars to Divorce ${ }^{108}$}

The Divorce Act includes no provision requiring the court to grant a divorce decree upon proof of the specified grounds and the absence of the designated statutory bars to relief. ${ }^{100}$ Notwithstanding the omission of such provision, it is submitted that no general discretion vests in the court to refuse divorce and that the only circumstances that will justify denial of the decree are the absolute and discretionary bars to

106 D. M. Selby, loc. cit. supra, n. 15, at 487.

107 The Law Commission (England), supra, n. 104, at para. 32.

108 See supra, sub-heading "Bars to Relief under Section 4 (1) (e)."

100 Compare Marriage and Divorce Act, R.S.C. 1952, c. 176, s. 5; Divorce and Matrimonial Causes Act, 1857, supra, n. 36, s. 31 . 
relief defined in section 9 of the Act. Thus, the traditional discretionary bars to divorce, namely, the petitioner's adultery, cruelty, desertion, culpable delay, and conduct conducing to the respondent's offence, would appear no longer applicable even in respect of the grounds of divorce set out in section 3 of the Act. ${ }^{110}$

\section{Consent; Admission; Default}

Section $9(1)$ (a) of the Divorce Act provides that:

9. (1) On a petition for divorce it shall be the duty of the court

(a) to refuse a decree based solely upon the consent, admissions or default of the parties or either of them, and not to grant a decree except after a trial which shall be by a judge, without a jury.

The language of this provision is sufficiently wide to exclude any undefended petitions for divorce but this could not have been the intention of the Federal Parliament since the possibility of the respondent entering no defence is contemplated by the provisions of section 4 (1) (c) and section 8 of the Act. It is submitted that the object of section 9 (1) (a) is merely to secure a trial of the issues in the court and that it does not preclude divorce being granted solely on the basis of admissions made under oath during the course of the divorce proceedings. ${ }^{111}$

\section{Collusion}

Section 9(1) (b) requires the court to satisfy itself that there has been no collusion in relation to a petition for divorce and to dismiss the petition if it finds that there has been collusion in presenting or prosecuting it. ${ }^{112}$ Collusion thus constitutes an absolute bar to divorce in respect of all grounds designated in sections 3 and 4 of the Divorce Act. Section $9(1)$ (b) appears to place the onus on the petitioners to prove the absence of collusion and constitutes a reversal of the previous rule of law. ${ }^{113}$ It is probable that the Canadian courts will in this context follow the decision in Emanuel v. Emanuel, ${ }^{114}$ wherein it was held that there is a presumption against collusion which is provisional and counterbalanced by circumstances which lead to a reasonable suspicion thereof, whereupon it falls upon the petitioner to negative collusion.

\section{Condonation and Connivance}

Section 9 (1) (c) provides that, where a decree of divorce is sought under section 3 , the court must satisfy itself that there has been no condonation or connivance on the part of the petitioner and must dismiss the petition if the petitioner has condoned or connived at the act or conduct complained of unless, in the opinion of the court, the public interest would be better served by granting the decree. ${ }^{113}$ Condonation and connivance have accordingly been converted from absolute to dis-

110 But see Williams v. Williams and DesRoches (1967), 52 M.P.R. 368, wherein the discretionary bar of the petitioner's adultery was deemed to exist notwithstanding the absence of statutory authority. In this case he court exercised the discretion "in favour of "the petitioner.

111 See Elliott v. Elliott and Cook, [1933] O.R. 206; [1933] 2 D.L.R. 40, wherein the term "admissions" in Ont. R. 14 was held to refer to admissions made in the pleadings or by counsel at trial and not to admissions made upon examination for discovery.

112 For analysis of the statutory definition of collusion in the Divorce Act, s. 2(c), see supra, text to and contents of nn. 9-17.

113 See Dutko v. Dutko, [1946] 3 W.W.R. 295; [1947] 4. D.L.R. 471; 54 Man. R. 329. See also Rhodenizer v. 'Rhodenizer [1953] 2 D.L.R. 99; 31 M.P.R. 127 (N.S.); Riley v. Riley [1950] 1 W.W.R. 548; [1950] 2 D.L.R. 694; 57 Man. R. 527.

114 Supra, n. 10.

116 See the exclusionary definition of condonation of the Divorce Act, s. 2(d), discussed supra, text to nn. 18-25. 
cretionary bars and, unlike the absolute bar of collusion, apply only in respect of the grounds of divorce set out under section 3 of the Divorce Act. As is the case with collusion, however, the onus of proof would now appear to fall on the petitioner to prove an absence of condonation and connivance. ${ }^{110}$

In determining whether the public interest would be better served by granting a decree notwithstanding condonation or connivance on the part of the petitioner, it is possible that the courts will have regard to the criteria established in Blunt v. Blunt, ${ }^{117}$ wherein the discretionary bar of the petitioner's adultery was in issue. In that case the House of Lords held that the following circumstances ought to be considered in determining whether the statutory discretion should be exercised "in favour of the petitioner":

(a) the position and interest of any children of the marriage;

(b) the interest of the party with whom the petitioner has been guilty of misconduct, with special regard to the prospect of their future marriage;

(c) the question whether, if the marriage is not dissolved, there is a prospect of reconciliation between husband and wife; ...

(d) the interest of the petitioner, and, in particular, the interest that the petitioner should be able to remarry and live respectably; [and] ...

[e] the interest of the community at large, to be judged by maintaining a true balance between respect for the binding sanctity of marriage and the social considerations which make it contrary to public policy to insist on the maintenance of a union which has utterly broken down.

Section $9(2)$ of the Divorce Act provides that "any act or conduct that has been condoned is not capable of being revived so as to constitute a ground for divorce described in section 3." It is submitted that this subsection does not circumscribe the discretionary bar of condonation established by section 9 (1) (c). The joint operation of the two provisions may perhaps best be defined by reference to hypothetical facts. Consider the case where a husband has committed adultery and his wife condoned the offence but the husband thereafter resumed his association with the adulteress and acts of intimacy falling short of adultery occurred. Under the law existing prior to the new Divorce Act the wife could complain of the condoned adultery by asserting revival of the offence by reason of the husband's subsequent misconduct. If the court accepted the wife's assertion and found the condoned adultery revived, then a decree of divorce would issue as of right since the absolute bar of condonation would be erased by operation of the doctrine of revival. 118 Today, the wife's position in the above circumstances has changed. Under sections 9 (1) (c) and 9(2) of the Divorce Act the wife would no longer be entitled as of right to a decree of divorce because the doctrine of revival has been abolished by section 9 (2). The court would, however, now be required to exrecise its discretion in accordance with section $9(1)$ (c) and would grant the decree only

116 See supra, text to n. 114. See also Maddock v. Maddock, [1958] O.R. 810 (connivance); Tilley v. Tilley, [1949] P. 240; [1948] 2 All E.R. 1113; 118 L.J.R. 929 (condonation) Clark v. Clark and Holt, [1947] 1 W.W.R. 1101 (B.C.) (condonation), Churchman v. Churchman, [1945] P. 44, 114 L.J.P. 17 (connivance); Craig v. Craig and Robinson, [1943] O.W.N. 651 (condonation). But compare Plummer. v. Plummer (1962). 38 W.W.R. (N.S.) 193; 31 D.L.R. (2d) 723 (B.C.) (condonation); Mogen v. Mogen, [1948] 2 W.W.R. 1151; [1949] i D.L.R. 388 (Alta.) (condonation); Kawala v. Kawala and Mason, [1951] O.W.N. 244 (connivance); Hill v. Hill and Johnston, [1938] 1. W.W.R. 94; [1938] 1 D.L.R. 774 (Sask.) (connivance); McPherson v. McPherson (No. 2), (19331 2 W.W.R. 513 (Alta.) (connivance)

117 [1943] A.C. 517, 525; [1943] 2 All E.R. 76; 112 L.J.P. 58.

118 Cundy v. Cundy, Smith and Finch, [1956] 1 W.L.R. 207n; [1956] 1 All E.R. 245; 100 Sol. J. 134. See also Heath v. Heath and Stark (1959); 31 W.W.R. (N.S.) 508; 22 D.L.R. (2d) 269 (Sask.); Stevenson v. Stevenson (1958), 26 W.W.R. (N.S.) 211 (Alta.). 
if the court considered that the public interest would be better served by granting it.

It has already been observed that connivance is now a discretionary bar to divorce and that the courts may, but will not necessarily, exercise the discretion in accordance with the criteria defined in Blunt v. Blunt. ${ }^{119}$ It is probable that, in exercising the discretion in respect of the petitioner's connivance, the courts will more readily grant a divorce decree in cases of passive connivance, but there is nothing that precludes the courts from granting a decree even though active connivance is established. In all cases, however, the court must be satisfied that the public interest would be better served by granting the decree.

It should be further observed that the discretionary bar of connivance is now extended beyond the context of adultery and applies in respect of all matrimonial offences which constitute grounds for divorce under section 3 of the Divorce Act. It is presumably applicable, therefore, whenever such matrimonial offence of the respondent has been caused by or has been knowingly, wilfully or recklessly permitted by the petitioner as an accessory. ${ }^{120}$

\section{Bars to Relief under Section $4^{121}$ \\ Anticipated Future Cohabitation}

Where a decree of divorce is sought pursuant to the grounds set out in section 4 of the Divorce Act, it is the duty of the court under section $9(1)$ (d) to refuse the decree if there is a reasonable expectation that cohabitation will occur or be resumed within a reasonably foreseeable period. It will be observed that under this provision the court must refuse a decree if it concludes that there is a reasonable expectation of matrimonial cohabitation within the foreseeable future. If the court is in doubt as to the possibility of such cohabitation being established or resumed, it would seem appropriate for the court to order an adjournment pursuant to the provisions in section 8 (1) in order that the opportunity for reconciliation of the spouses may be duly considered. The operation of section $9(1)$ (d) is confined to the circumstances where a decree for divorce is sought under section 4 and it has no relevance in respect of a decree sought under section 3 . It is submitted that section 9(1) (d) will have a strictly limited application because, where a permanent breakdown of marriage is established by reason of the circumstances designated in section $4(1)$, paragraphs (a) to (e),,$^{122}$ the natural inference to be drawn is that there is no reasonable prospect that matrimonial cohabitation will occur or be resumed. It is further submitted that the courts should not and will not refuse a decree pursuant to section $9(1)$ (d) unless there is reason to believe that both spouses would be willing to establish or resume cohabitation. The fact that one of the spouses is so willing would appear to be insufficient since matrimonial cohabitation necessarily implies a bilateral intention in the spouses to assume or resume the matrimonial relationship. Thus, in Mummery v. Mummery, ${ }^{123}$ Lord Merriman, P., stated:

119 See supra, text to and contents of $n$. 117 .

120 See Maddock v. Maddock, supra, n. 116; Woodbury v. Woodbury, [1949] P. 154; [1948]

2 All -E.R. 68; 64 T.L.R. 549; Churchman v. Churchman, supra, n. 116.

121 See supra, sub-heading "Bars to Relief under Section 4(1) (e)."

122 See supra, text to and contents of n. 87.

123 [1942] P. 107; [1942] 1 All E.R. 553; 111 L.J.P. 58. 
I doubt whether any judge could give a completely exhaustive definition of cohabitation, and certainly I am not going to attempt to do so, but at least a resumption of cohabitation must mean resuming a state of things, that is to say, setting up a matrimonial home together, and that involves a bilateral intention on the part of both spouses so to do.

\section{Protection of Children}

Section 9(1) (e) provides that where a decree of divorce is sought under section 4 of the Divorce Act, the court must refuse the decree if there are children of the marriage ${ }^{124}$ and the granting of the decree would prejudicially affect the making of reasonable arrangements for their maintenance. Like section $9(1)(d)$, the bar to divorce arising under section $9(1)$ (e) is absolute and applies only where a decree of divorce is sought on the grounds established by section 4. It is, in my opinion, unfortunate that corresponding protection is denied to the children of the marriage where the decree of divorce is sought under section 3, for there appears to be no justification for subordinating the rights of the children to those of the spouses merely by reason of the nature of the complaint in the petition for divorce. In England, similar but not identical provisions apply to all petitions for dissolution of marriage. Section 33 of the Matrimonial Causes Act 1965 (Imp.) provides as follows:

33. (1) Notwithstanding anything in Part I of this Act but subject to the following subsection, the court shall not make absolute a decree of divorce or nullity of marirage in any proceedings ... . unless it is satisfied as respects every relevant child who is under sixteen that-

(a) arrangements for his care and upbringing have been made and are satisfactory or are the best that can be devised in the circumstances; or

(b) it is impracticable for the party or parties appearing before the court to make any such arrangements.

(2) The court may if it thinks fit proceed without observing the requirements of the foregoing subsection if-

(a) it appears that there are circumstances making it desirable that the decree should be made absolute ... without delay; and

(b) the court has obtained a satisfactory undertaking from either or both of the parties to bring the question of the arrangements for the children before the court within a specified time. ${ }^{125}$

The efficacy of these provisions in ensuring financial security for children of the marriage has been seriously questioned by Dr. Olive Stone, ${ }^{126}$ who has stated:

Unfortunately, however [they] do not seem to have fulfilled the expectations of those who enacted them. In its recent report on Reform of the Grounds for Divorce, The Field of Choice, the Law Commission states that the provisions have been widely criticised as inadequate, both in their scope and in the way that they are working in practice. . . .127 Uneasiness appears to exist particularly in regard to two aspects of the provisions. In the first place, there seems to be some evidence that the divorce judges rarely probe deeply into the arrangements proposed by the parties for the children, and if these arrangements seem prima facie reasonable they are usually approved. The Law Commission points out that, even in respect of the alleged facts on which the petition is based, 'In ten minutes, the average time of hearing in an undefended case, the Judge obviously cannot carry out a thorough inquisition.'128 This would seem to apply a fortiori to the arrangements for the children. Secondly,

128 For definition of "children of the marriage", see Divorce Act, s. 2(b) discussed supra, subheading "Child; Children of the Marriage."

125 See supra, n. 21. Compare with the Matrimoniai Causes Act, 1959, supra, n. 13 s. 71, as am. the Matrimonial Causes Act 1965, supra, n. 19, s. 12. See also Matrimonial Proceedings Act 1963, supra, n. 2, s. 46.

120 Olive M. Stone, The Importance Of Children In Family Law (1967), 6 West. L. Rev. 21. 27. See also Law Commission (England), Working Paper No. 15: Atrangements For The Care And Upbringing Of Children, Feb. 6, 1968 (Report prepared by Mr. John Hall, University of Cambridge, England).

127 Supra, n. 104, para. 47

128 Id., at para. 60 . 
there is no adequate follow-up machinery to ensure that the arrangements approved for the children work satisfactorily, or even that they are adhered to. The Report of a Group appointed by the Archbishop of Canterbury, published in July $1966^{129}$ recommended that the court should have a duty always to notify the children's department of the appropriate local authority of custody arrangements for children after divorce.

Neither the Archbishop's Group nor the Law Commission is satisfied of the practibability or desirability of attempting to differentiate radically between marriages with children and those without.130 The Law Commission favours more detailed pleadings and regards the possibility of the intervention of counsel to represent the interests of the public or the children as feasible. ${ }^{131}$

It is relevant to consider the effect of section 9 (1) (e) in the not uncommon circumstance that arises when the party to a divorce proceeding contemplates an early remarriage. Such marriage would clearly tend to prejudice the provision of reasonable maintenance for children of the dissolved marriage since the divorcee will rarely be financially capable of supporting two families and will be naturally inclined to favour the competing claims of his second wife and of their children. The observations of Hart, J., in Kearns v. Kearns, ${ }^{132}$ might suggest that the children's right to financial security must be subordinated to the parent's right to a second chance at marital happiness, but such a conclusion would render the protection afforded by section 9 (1) (e) largely illusory.

Although the language of sction 9 (1) (e) does not so provide, it would appear that the court may order an adjournment of the proceedings for divorce for the purpose of allowing the parties an opportunity of making reasonable arrangements for the maintenance of the children of the marriage. ${ }^{133}$

Under section 9 (1) (e) an onus presumably falls upon the petitioner to satisfy the court that the granting of the decree of divorce would not prejudicially affect the making of reasonable arrangements for the maintenance of the children. It is uncertain, however, whether the court discharges its statutory obligation merely by acting upon a prima facie case established by the petitioner's uncontradicted sworn evidence since the section might be interpreted as imposing an inquisitorial function upon the court. With respect to a not dissimilar provision of the Matrimonial Causes Act 1959 (Australia), as amended in $1965,{ }^{134}$ the opinion has been extra-judicially expressed by the Chief Justice of the Supreme Court of Tasmania ${ }^{135}$ that the role of the court remains judicial and not inquisitorial and accordingly there is no independent duty imposed on the court to take active steps itself to inquire into the effect of a decree upon the provision of reasonable maintenance for the children of the marriage.

\section{Corollary Relief}

Sections 10 and 11(1) of the Divorce Act empower the court to

129 Putting Asunder: A Divorce Law For Contemporary Society, S.P.C.K., 1966, para. 57 and Appendix $\mathrm{D}$.

130 Putting Asunder, para. 59; see also supra, n. 104, paras. 50-57.

131 Supra, n. 104, para. 62.

132 Supra, n. 85. See also text to $\mathrm{nn} .82$ and 83.

133 A general power of adjournment is conferred by Alberta Divorce Rule 568 (3). supra, n. 26.

13. See supra, n. 125.

135 Sir Stanley Burbury, Some Extra-Judicial Reflections Upon Two Years' Judicial Experience of The Commonwealth Matrimonial Causes Act, 1959 (1963), 36 Aust. L.J. $283,294$. 
make interim ${ }^{136}$ or permanent ${ }^{137}$ orders for the maintenance of either spouse and for the maintenance of and the custody, care and upbringing of the children of the marriage. The most significant change arising under these sections is the legislative recognition of mutual rights and obligations of support between the spouses. It is probable that such recognition will not result in any significant demand for maintenance by husbands and that the courts will ordinarily order a wife to pay maintenance to her husband only where he is unable to support himself by reason of disability of mind or body or by reason of his incapacity to secure gainful employment. A further substantial change arising by operation of section 11 (1) is that the court is now empowered to order either spouse to pay a lump sum for the maintenance of a spouse and/or the children of the marriage. ${ }^{138}$

The granting or withholding of an order to secure or to pay a lump sum or periodic sums for the maintenance of a spouse is within the discretion of the court which is to be exercised having regard to the conduct of the parties and the condition, means and other circumstances of each of them. There is nothing to prevent the court awarding maintenance to a spouse against whom a decree of divorce has been obtained ${ }^{139}$ and the adultery of a spouse does not, of itself, preclude an award of maintenance in his or her favour, though it may be relevant to the exercise of the court's discretion.

Section 11 (1) of the Divorce Act would appear to reflect considerations corresponding to those advocated by Hofstadter, J., in Doyle v. Doyle,,$^{140}$ who stated:

In evolving a modern system for fixing alimony and support the elements of

(1) fault, (2) financial capacity and (3) need must be reappraised.

Alimony should not be a reward for virtue nor a punishment for guilt. The

element of fault should be de-emphasized. Fault should not be a bar to alimony

136 The Dlvorce Act, s. 10, which regulates the powers of the court to make interim orders, provides as follows:

"10. Where a petition for divorce has been presented, the court having jurisdiction to grant relief in respect thereof may make such interim orders as it thinks fit and just

(a) for the payment of alimony or an alimentary pension by either spouse for the maintenance of the other pending the hearing and determination of the petition accordingly as the court thinks reasonable having regard to the means and needs of each of them;

(b) for the maintenance of and the custody, care and upbringing of the children of the marriage pending the hearing and determination of the petition; or

(c) for relieving either spouse of any subsisting obligation to cohabit with the other."

187 The Divorce Act, s. 11(1), reads as follows:

"11. (1) Upon granting a decree nisi of divorce, the court may, if it thinks it fit

and fust to do so having regard to the conduct of the parties and the conditlon

means and other circumstances of each of them, make one or more of the following orders, namely:

(a) an order requiring the husband to secure or to pay such lump sum or periodic sums as the court thinks reasonable for the maintenance of both or either (1) the wife, and

(ii) the children of the marriage;

(b) an order requiring the wife to secure or to pay such lump sum or periodic sums as the court thinks reasonable for the maintenance of both or elther (i) the husband, and

(ii) the children of the marriage; and

(c) an order providing for the custody, care and upbringing of the children of the marriage.'

188 Prior to enactment of this provision, the courts refused to order the payment of a lump sum unless the parties consented thereto: see Maynard v. Maynard, [1950] lump sum [1950]2 D.I.R. 121, aff'd. [1951] S.C.R. 346; [1951] 1 D.i.R. 241; Green v Hammond, [1941] 3 W.W.R. 161; [1941] 4 D.L.R. 335 (Alta.).

139 Clearly such a power may be exercised where the petition for divorce is based upon the Divorce Act, s. 4(1) (e), and there appears to be no valid reason for denying general recognition to such power irrespective of the ground upon which the decree of divorce is sought: see Divorce Act, 8. $9(1)(f)$, and Doyle v. Doyle (1957.), 158 N.Y.S. 2d 909 .

140 Id., at 911-913. 
except in cases of gross culpability, such as infidelity or abandonment.141 In most cases neither party is at fault or both are in some degree. Generally, family break-ups are not due to specific acts of either spouse, legal fictions notwithstanding. They result rather from general malaise to which both have contributed. Fault usually comes after malaise has set in; it is the symptom not the cause of domestic discord.

The factor of need, too, must be adjusted to women's new position in our society. The married woman has come a long way since the days of Blackstone when she had no legal identity apart from her husband's; she is no longer the Victorian creature, 'something better than her husband's dog, a little dearer than his horse.' She is now the equal of man, socially, politically and economically. It is time that consonant with this new approach to woman's status we develop a modern basis for fixing alimony and support which will have its roots in reality.

A practical approach in awarding alimony would be to proceed on the basis of what we may term 'net need', the wife's actual financial requisite less her current assets and earning potential in relation to her husband's capacity to pay. If a woman proves need she should have support-but when she can, she should also be required to mitigate her husband's burden either by her own financial means or earning potential or both. The want alimony seeks to solve is economic-for alimony is basically the statutory substitute for the marital obligation of a husband to support his wife.

Each case must be treated as its particular circumstances indicate for there are many variables that should be taken into account in the determination of alimony. If a woman has contributed however indirectly to her husband's career and helped to increase his substance she may rightfully be regarded as entitled to a share of his gain. A woman who has devoted the greater part of her time to caring for a home and children has had little opportunity to learn the skills necessary to earn a living in our competitive society. The court should and will take cognizance of her plight.

But the same considerations do not operate in the cast of a young woman who in all but form has remained alien to her husband's interest. Why should ex-wives and separated women seek a preferred status in which they shall toil not, neither shall they spin. Alimony was originally devised by society to protect those without power of ownership or earning resources. It was never intended to assure a perpetual state of secured indolence. It should not be suffered to convert a host of physically and mentally competent women into an army of alimony drones.

Ironically, inflated alimony awards are frequently not only financially disastrous to the man but psychologically deleterious to the woman. She remains hopelessly entangled in the web of the past, never establishing a new and independent life but 'wandering between two worlds one already dead the other powerless to be born.'

In the field of matrimonial litigation and alimony awards the husband and wife are not the sole parties. Society itself has locus standi for it is deeply affected in vital aspects. For the benefit of all concerned, we must proceed in a climate of sanity that will reflect modern reality and in a spirit of sympathetic understanding that will achieve justice and equity.

The amount of maintenance to be awarded is also within the discretion of the court which is presumably to be exercised having regard to the aforementioned considerations, namely, the conduct of the parties and their condition, means and other circumstances. It would appear, therefore, that the claimant's earning capacity or potential, though not realized, is relevant to the amount of maintenance that may be properly awarded. ${ }^{142}$

141 It is submitted that misconduct on the part of the claimant should not necessarily constitute an absolute bar to financial rellef although it may, in the circumstances of the particular case, be relevant or even decisive to a determination of the right to maintenance.

142 Although the claimant's independent income has always been regarded as relevant to a determination of the amount of maintenance, there has hitherto been a difference of judicial opinion as to whether or not the court should take into account the earning capacity of a claimant who declines the opportunity of seeking gainful employment. Some decisions suggest that, in determining the proper amount, the court should ignore any income that such a claimant would be likely to receive if employed, but others appear to have taken the factor or earning capacity into account: see J.-P.C. v. J.-A.F., [1955] 2 W.L.R. 973; [1955] 2 All E.R. 85, aff'd. with varlation [1955] P. 125; [1955] 3 W.L.R. 72; [1955] 2 All E.R. 617; Le Roy-Lewis v. 
Section 11 (1) does not require that orders for unsecured maintenance shall be limited to a term not exceeding the joint lives of the spouses $^{143}$ and the duration of such orders may now be regarded as falling within the general discretion of the court. ${ }^{144}$

The power of the court to make orders pursuant to section 11 (1) is exercisable "upon granting a decree nisi of divorce." Such orders cannot be made, therefore, if the petition for divorce is dismissed. It would appear, however, that the phrase "upon granting a decree nisi" may be broadly interpreted to permit an application for maintenance or custody subsequent to the decree nisi provided that such application is made within a reasonable time. ${ }^{140}$

The powers of the court to discharge or modify a corollary order made pursuant to section 11 (1) are defined in section 11 (2), which reads as follows:

11. (2) An order made pursuant to this section may be varied from time to time or rescinded by the court that made the order if it thinks it fit and just to do so having regard to the conduct of the parties since the making of the order or any change in the condition, means or other circumstances of either of them.

Since this subsection would appear to confer exclusive jurisdiction to vary or rescind upon the court that made the order, ${ }^{146}$ difficulties may be envisaged where the parties have left the province wherein the order was obtained and assumed residence in another province, for the courts of the latter province lack jurisdiction to vary or rescind the order. ${ }^{147}$ It is possible, however, that the difficulties may be eliminated if the order is registered in the latter province pursuant to the provisions of the Reciprocal Enforcement of Maintenance Orders Act and this statute authorizes the court in the registering province to exercise the

Le Roy-Lewis, [1955] P. 1; [1954] 3 W.L.R. 549; [1954] 3 All E.R. 57; Rose v. Rose, [1951] P. 29; [1950] 2 Al E.R. 311; Dixon v. Dixon, [1950] 2 W.W.R. 49; 58 Man. R. 48; Hall v. Hall, [1947] O.W.N. 997; M. v.M. [1947] O.W.N. 474; [1947] 3 D.L.R. 74; Newton v. Newton (No. 2), [1927] 1 W.W.R. 106; [1927] i D.L.R. 756 (Man.); Keweluk v. Keweluk, [1923]' 2 W.W.R. 78; [1923] 2 D.L.R. 979; 17 Sask. L.R. 18; Hudson v. Hudson, [1914] 26 O.W.R. 688; 6 O.W.N. 503; Goodfriend v. Goodfriend, [1912] 21 O.W.R. 637; 3 O.W.N. 784.

143 Compare Divorce and Matrimonial Causes Act 1866 (Imp.), 29 Vict., c. 32, s 1; Matrimonial Causes Act, R.S.O. 1960, c. 232, s. 2.

144 But see The Canadian Divorce Act, s. 19(1)(d) which empowers the courts to make rules of court providing for the enforcement of corollary orders after death. The powers conferred by this provision have not, as yet, been exercised.

146 See Power on Divorce, supra, n. 8, at 535:

". although the Act of 1857 ( making of the decree and the Rules prescribe'a time within which the application is to be made, it is settled that it may be made within a reasonable time, depending on the circumstances of the case, and that even a long delay is not fatal if excusable on the circumstances of the case, and that even a the making of an application would and it is has been held to be excusable where the making of an application would have been futile because the hust
or definite prospects thereof."

See also the cases cited therein: Oliver v. Oliver (1963, 42 W.W.R. (N.S.) 634 (B.C.): Bailey v. Bailey (1960), 31 W.W.R. (N.S.) 289; 23 D.L.R. (2d) 574 (B.C.): McMahon v. McMahon (1956), 18 W.W.R. (N.S.) 284 (B.C.): Simmonds v. Simmonds, [1956] V. McMahon (1956), 18 W.W.R. (N.S.) 284 (B.C.) Simmonds v. Simmonds, (1956) [1947] 2 All E.R. 744; 117 L.J.R. 119; Todd v. Todd, [1942] 3 W.W.R. 653; [1942] 4 D.L.R. 698 (Sask.); Thorgeirson v. Thorgeirson, $1942 \mid 2$ W.W.R. 339; |1942| 3 D.L.R. 767; 50 Man. R. 245; Fisher v. Fisher, [1942] P. 101; [1942] 1 All E.R. 438; 111 L.J.P. 28. And see Bryant v. Bryant (1963), 42 W.W.R. (N.S.) 37,39 D.L.R. (2d) 110 (B.C.); Philichowsky.v. Pilichowsky, [1947] 1 W.W.R. 257; 2 D.L.R. 444, aff'd [1948] 1 W.W.R. 590; [1948] 2 D.L.R. 862 (Sask.).

140 But see Alberta Divorce Rule 574, supra, n. 29.

147 But see infra, text to and contents of $\mathrm{nn} .159$ and 160.

Compare section 25(3) of the Divorce Act which provides that corollary orders made in divorce proceedings instituted prior to the commencement of the Act may be varied or rescinded by "the court that would have had jurisdiction to grant the decree of divorce corollary to which the order was made if this Act had been in force." This provision, in limited circumstances, empowers variation of a corollary order by the court of a province other than that wherein the order was obtained. 
same powers with respect to orders so registered as the court would exercise over its own orders. ${ }^{148}$

It will be observed that the discretionary power of the court to vary or rescind corollary orders must be exercised having regard to the conduct of the parties and their respective condition, means or other circumstances. The power is not expressly confined to orders for unsecured periodic sums and may presumably therefore be exercised also with respect to orders to secure maintenance ${ }^{149}$ and orders for the payment of a lump sum. ${ }^{150}$ It is probable that a variation may be ordered to operate retrospectively even though this has the effect of remitting payments already due, ${ }^{152}$ and it may also be permissible for the court, in exceptional circumstances, to order the repayment of any periodic sums or lump sum already paid. ${ }^{152}$

There is no explicit requirement that the court must vary or discharge a corollary order in the event of the subsequent remarriage of either party or the subsequent adultery of the recipient and these circumstances must now be regarded only as relevant and not decisive to a determination of the right to variation or rescission of the order. ${ }^{153}$

Section 12 of the Divorce Act seeks to more effectively secure the proper discharge of obligations arising under corollary orders and provides that where such orders are made pursuant to sections 10 and 11 , the court may direct that payments thereunder be made either to the husband or wife or to a trustee or administrator approved by the court, and may impose such terms, conditions or restrictions as the court thinks fit and just.

\section{Decrees and Orders}

Section 13(1) provides that every decree of divorce shall in the first instance be a decree nisi and no such decree shall be made absolute until three months have elapsed from the granting thereof and the court is satisfied that every right of appeal from the judgment granting the decree has been exhausted. ${ }^{154}$ But if the court is satisfied that special circumstances render it in the public interest for the decree absolute to be granted before the expiration of three months from the granting

148 See Re Short v. Short (1962), 40 W.W.R. (N.S.) 592 (Alta.), wherein it was held that an Alberta court has the same powers with respect to an order registered under the Reciprocal Enforcement of Maintenance Orders Act, S.A. 1958, c. 42, as it would have if it had made the order itself and, therefore, it can discharge, vary or suspend its operation by reason of a material change in the circumstances of the parties.

149 Orders to secure have previously been regarded as final and irrevocable: see Cotton v. Cotton (1967), 58 W.W.R. (N.S.) 65, 70-71 (B.C.); MacDonald v. MacDonald, [1952] O.R. 754; [1952] 4 D.L.R. 457.

150 Compare Maynard v. Maynard, supra, n. 138, wherein it was held that the court has power to grant a lump sum only with the consent of the parties, and the court has no jurisdiction to vary the amount so awarded.

151 See MacDonald v. MacDonald and Howard, [1957] O.W.N. 419; 10 D.L.R. (2d) 309 (Thompson, J.: "An order for maintenance under the Matrimonial Causes Act, R.S.O. 1950, 226, in my opinion, may be varied at any time, not only as to payments in futuro, 1950, 226, in my opinion, may be varied at any time, not only as to payments in futuro,
but as well to arrears."). See also MacDonald v. MacDonald [1964] $P$. 1; [1963] 3 W.L.R. 350; [1963] 2 All E.R. 857.

152 But see Young v. Young (No. 2), [1962] P. 218; [1961] 3 W.L.R. 1041; [1961] 3 All E.R. 793, wherein the court was deemed to lack jurisdiction to order repayment by a wife of money received by her under an order of the court even though she had been guilty of concealing material facts which justified variation of the order. See also Law Commission (England). Working Paper No. 9: Matrimonial and Related Proceedings-Financial Relief, Apr. 25, 1967, paras. 95-97, wherein it is recommended that the court should be able to remit arrears, to backdate variations and, where the payee has failed to disclose a material change of circumstances, to order repayment of sums already paid.

153 Compare Matrimonial Causes Act, supra, n. 143, s. 2(1), which includes the proviso "so long as she remains chaste." See also s. 2(2) which provides that payments of unsecured maintenance "shall cease on the wife marrying again."

154 For new rules of procedure regulating applications for decree absolute and the right of intervention, see Alberta Divorce Rules 569-573, supra, n. 29. 
of the decree nisi, the court may, upon or after granting the decree nisi, fix a shorter period after which the decree may be made absolute or, in its discretion, grant the decree absolute without further delay. This power to expedite the granting of the decree absolute is defined in section 13 (2) which declares that such power is conditional upon the consent of the parties and their undertaking that no appeal will be taken or that any appeal already taken has been abandoned. ${ }^{165}$ Section $13(3)$ provides that where a decree nisi has been granted but not made absolute, any person may intervene in the proceedings to show cause why the decree should not be made absolute by reason of its having been obtained by collusion, by reason of the reconciliation of the parties or by reason of any other material facts, and, in any such case, the court may, by order, rescind the decree nisi, require further inquiry to be made, or make such further order as the court thinks fit. ${ }^{158}$ By virtue of section $13(4)$, if the petitioner has made no application for the decree nisi to be made absolute, the respondent may apply to have the decree made absolute, and such application may be made at any time after the expiration of one month from the earliest date on which the petitioner could have applied for the decree absolute. ${ }^{157}$ The petitioner's failure to make application for the decree absolute does not, however, entitle the respondent to move to have the decree nisi vacated. ${ }^{158}$

Section 14 of the Divorce Act stipulates that a decree of divorce or corollary order made under the Act shall have legal effect throughout Canada. To facilitate the enforcement of such corollary orders, section 15 further provides that these orders may be registered in any other superior court in Canada and may be enforced ${ }^{159}$ in like manner as an order of that superior court or in such other manner as may be provided for by rules of court or regulations made under section $19 .{ }^{160}$

Section 16 provides that where a decree of divorce has been made absolute under the Act, either party to the former marriage may marry again. It is probable that the intent of this section is to affirm the principle set out in Re Schepull and Bekeschus and Provincial Secretary, ${ }^{161}$ wherein it was held that the relationship of affinity is terminated by divorce. It is submitted, however, that such intent would have been better realized had the section stipulated that where a decree of divorce has been made absolute "it shall be lawful for the respective parties

150 Quaere whether such consent and undertaking may be submitted to the court in writing. If not, the granting of a decree absolute cannot be expedited in an uncontested proceeding unless the respondent appears and gives such consent and undertaking. One may seriously question the wisdom of requiring the respondent's consent where the public interest renders expedition of the decree absolute desirable. Compare Matrimonial Causes Act (Australia), 1959, supra, n. 13, s. 72 (3); Matrimonial Proceedings Act 1963, supra, n. 2, s. 33.

156 See also Alberta Divorce Rule 573, supra, n. 29.

As to the power of the court to direct intervention by the Queen's Proctor, see Alberta Divorce Rule 568 (3) and (4). As to the power of the Queen's Proctor to intervene before pronouncement of the decree nisi, see Alberta Divorce Rule 566 .

157 See also Alberta Divorce Rule 571, supra, n. 29. See Harding v. Harding (1968), 67 D.L.R. (2d) 371 (N.S.), wherein it was held that the granting of a decree absolute is a procedural and not a substantive matter and could not be made on the application of the respondent in the absence of authorization under the provinclal rules of court. Note, however, that this decision was pronounced prior to the proclamation of the new Divorce Act. As to the constitutional power of the Federal Parliament to enact procedural provisions, see Power on Divorce, supra, $\mathbf{n}$. 8, at 2-3.

158 See Divorce Act, s. (3,4), and Alberta Divorce Rule 571, supra, n. 29. Compare fomrer Alberta Divorce Rule 659 (a).

159 Quaere whether the term "enforced" may be broadly construed so as to permit variation or discharge of the corollary order by the court wherein such order is registered.

160 For procedure regulating registration under section 15, see Alberta Divorce Rule 575. For analysis of section 19, see infra, subheading "Rules of Court," supra, $n$. 29 .

161 [1954] O.R. 67; [1954] 2 D.L.R. 5. 
thereto to marry again as if the prior marriage had been dissolved by death." 182

\section{Appeals}

Appeals to the court of appeal ${ }^{103}$ from an order or judgment pronounced under the Divorce Act are regulated by section 17 , which reads as follows:

17. (1) Subject to subsection (3), an appeal lies to the court of appeal from a judgment or order, whether final or interlocutory, other than a decree absolute, pronounced by a court under this Act.

(2) The court of appeal may

(a) dismiss the appeal; or

(b) allow the appeal and

(i) pronounce the judgment that ought to have been pronounced including such order or such further or other order as it deems just, or

(ii) order a new trial where it deems it necessary to do so to correct a substantial wrong or miscarriage of justice.

(3) An appeal under subsection (1) shall be brought by filing a notice of appeal in the court of appeal not later than fifteen days after the pronouncing of the judgment or the making of the order being appealed from.

(4) Except where a decree of divorce has been made absolute, the court of appeal or a judge thereof may, on special grounds, either before or after the expiration of the time fixed by subsection (3) for bringing an appeal, by order extend that time.

Although this section denies any right of appeal from a decree absolute, it does not preclude the rescission of a decree absolute on the ground that it was obtained by a fraudulent abuse of the process of the court. ${ }^{104}$

Section 18 provides that an appeal lies from a decision of the court of appeal to the Supreme Court of Canada but such appeal lies only on a question of law and by leave of the Supreme Court of Canada. ${ }^{165}$

\section{Rules of Court}

Section 19 (1) of the Divorce Act confers jurisdiction upon the court ${ }^{166}$ or court of appeal ${ }^{107}$ to make divorce rules regulating the pleading, practice and procedure in the courts, the sittings of the courts, the fixing and awarding of costs, the registration and enforcement of orders made under the Act including their enforcement after death, the duties of officers of the courts, and any other matter considered expedient to effectuate the purposes and provisions of the Act. ${ }^{188}$ Section 19 (2) of the Act, however, empowers the Governor in Council to make such regulations as he considers proper to assure uniformity in the rules of court made pursuant to section $19(1)$, and any such regulations prevail over the rules of court made under that subsection. ${ }^{169}$

162 See Matrimonial Proceedings Act 1963, supra, n. 2, s. 35; Matrimonial Causes Act 1959, supra, n. 13, s. 46.

163 See Divorce Act, s. 2 (f), discussed supra, sub-heading "Court of Appeal."

164 For discussion of the judicial power to rescind a decree absolute, see Power on Divorce, supra, n. 8, at 149-152.

166 The Divorce Act, s. 18, reads as follows:

18. (1) An appeal lies on a question of law to the Supreme Court of Canada with leave of that court from a decision of the court of appeal under section 17.

(2) Leave to appeal under this section may be granted within thirty days from the pronouncing of the judgment or order being appealed from or within such extended time as the Supreme Court of Canada or a judge thereof may, before the expiration of those thirty days, fix or allow.

166 See Divorce Act $\$$. 2 (e), discussed supra, sub-heading "Court."

167 See supra, n. 163.

168 As to the continuation of procedural laws which were in operation before the commencement of the Divorce Act, see s. $19(3)$.

169 At present, the only regulations made pursuant to the Divorce Act, s. 19 (2), relate to the creation of a Central Divorce Registry: see (1968), 102. Canada Gazette (Part II) 636. See aupra, n. 35 . 


\section{Evidence}

Section 20 of the Divorce Act declares that the laws of evidence of the province wherein divorce proceedings are instituted shall apply to the proceedings. ${ }^{170}$ Diversity in the laws of evidence applicable to divorce proceedings will accordingly persist in the Canadian provinces.

The major reform of the substantive law of divorce effected by the Divorce Act may render it desirable that the provincial Evidence Acts be reviewed and, in certain contexts, amended. For example, the retention of the privilege relating to questions tending to show adultery may be regarded as somewhat anomalous in the absence of any similar privilege applying to the other grounds for divorce established by sections 3 and 4 of the Divorce Act. ${ }^{171}$

\section{Admissions and Communications made in Course of Attempted Reconciliation}

Section 21(1) of the Divorce Act provides that a person nominated by the court under section 8 to assist the parties to a marriage with a view to their possible reconciliation is not competent or compellable in any legal proceedings to disclose any admission or communication made to him in his capacity as the nominee of the court for that purpose. ${ }^{172}$ Subsection (2) further provides that evidence of anything said or of an admission or communication made in the course of an endeavour to assist the parties to a marriage with a view to their possible reconciliation is not admissible in any legal proceedings. Subsection (1) specifically protects the interests of the nominated marriage counsellor by imposing upon him personally a statutory prohibition against disclosure, ${ }^{173}$ whereas subsection (2) is of more general application and imposes a statutory prohibition against disclosure upon all persons, including the parties and their counsellor. The language of subsection (2) is wide enough to exclude evidence of statements, admissions or communications made to persons other than counsellors nominated under section 8 , but the

170 The Divorce Act, s. 20, reads as follows:

"20. (1) Subject to this or any other Act of the Parliament of Canada, the laws of evidence of the province in which any proceedings under this Act are taken, including the laws of proof of service of any petition or other document, apply to such proceedings.

(2) For the purposes of this section.

(a) where any proceedings under this Act are taken before the Divorce Division of the Exchequer Court as the court for any province, the proceedings shall be deemed to be taken in that province; and

(b) where any petitions for divorce pending between a husband and wife are removed under sub-section (2) of section 5 by direction of the Divorce Division of the Exchequer Court into that Court for adjudication the proceedings shall of the Exchequer Court into that Court for adjudication, the proceedings shall province with which the husband and wife are or have been most closely associated according to the facts appearing from the petitions."

171 For recommendation that the existing privilege be abolished, see $J$. D. Payne, Adultery And The Privilege Against Self-Crimination (1968), Ottawa L. Rev.

172 Compare Matrimonial Causes Act 1959, supra, n. 13, ss. 5(1), 12(1), whereby a corresponding statutory prohibition is not confined to counsellors nominated by the court but extends to any person "authorized by an approved marriage guidance organization to offer marriage guidance on behalf of the organization."

For the conditions regulating the approval of marriage guldance organization, see Matrimonial Causes Act 1959, s. 10.

173 See Report of the Royal Commission on Marriage and Divorce (England), 1951-1955,

Cmd. 9678 (1956), at paras. 357-358: and unless there is complete freedom in discussion, the whole basis of conciliation may ultimately be destroyed. . .

The knowledge that if he is unsuccessful in his attempt at conciliation he may be called upon to give evidence in court is not likely to assist the counsellor in his task: and if there were to be frequent appearances in court of marriage guidance counsellors the public might well lose confidence in the marriage guidance movement, and those in difficulty would become increasingly hesitant to use their services. We think that [these] considerations cannot be met by anything short of a provision that the evidence of counsellors is not to be admissable in matrimonial cases." 
wisdom of extending the prohibition to a more general and undefined class of counsellors may well be question. ${ }^{174}$

\section{Quebec and Newfoundland Courts}

Section 22 (1) of the Divorce Act empowers the Governor in Council, on the recommendation of the Lieutenant Governor in Council of Quebec, to issue a proclamation declaring the Superior Court of Quebec to have divorce jurisdiction in that Province. Pending such proclamation, jurisdiction in divorce for the Province of Quebec is vested in the Divorce Division of the Exchequer Court. ${ }^{17}$ Corresponding provisions are set out in section 22(2) with respect to divorce jurisdiction for the Province of Newfoundland. These jurisdictional rules are supplemented by consequential amendments of the Exchequer Court Act. Thus, section 23 establishes a Divorce Division of the Exchequer Court and defines the constitution and powers of that Division. ${ }^{176}$

\section{Transitional Provisions}

Section 25(1) of the Divorce Act provides that any petition for divorce presented in Canada after the commencement of the Act shall be governed and regulated by the provisions thereof, whether or not the material facts or circumstances giving rise to the petition occurred wholly or partly before the coming into force of the Act. It may be of interest to contrast this provision with section $170(5)$ of the Domestic Relations Law, New York, wherein the "living apart" ground for divorce introduced in 1966 was declared to operate prospectively so as to preclude reliance upon a separation which occurred prior to the enactment of the section. In an analysis of the New York statute, the following opinion has been presented:

.. the new law requires that the separation agreement or decree two-year period must occur after September 1, 1966, with the result that these grounds will be unavailable until September 1, 1968 at the earliest. Such a postponement of the operation of the living apart grounds may be justified on the basis that the parties to prior separation agreements or decrees did not contemplate the legal consequence that such would provide grounds for divorce and hence it would be unfair to grant a divorce in such a situation even though the parties had demonstrated that they were irreconcilable. ${ }^{17 i}$

It is submitted, however, that the Canadian provision is to be preferred to that in New York since it recognizes that the public interest in legally dissolving a marriage which has permanently broken down shall prevail over the desires or even the presumed intentions of the parties. It is further submitted that the Canadian courts should not refuse a decree of divorce pursuant to section 9(1) (f) of the Divorce Act ${ }^{178}$ merely by reason of the fact that the parties did not contemplate the prospect of divorce at the time when a separation agreement was negotiated or a decree of judicial separation obtained.

Section 25(2) regulates proceedings for divorce commenced but not finally disposed of before the coming into force of the Divorce Act and

174 Compare Matrimonial Causes Act 1959, supra, n. 13 s. 16, and Matrimonial Proceedings Act 1963, supra, n. 2, s. 5, wherein corresponding statutory prohibitions extend only with respect to communications made by or to a counsellor numinated by the court. 175 See supra, $n$. 34 .

176 As to appeal from a decision of the Divorce Division of the Exchequer Court, see Divorce Act, ss. 2 (f), 17, discussed supra, sub-headings "Court of Appeal" and "Appeals" respectively.

177 See Henry H. Foster, Jr., and Doris J. Freed, The Divorce Reform Law 15 (The Lawyers Co-operative Publishing Company, Rochester, New York; 1966).

278 See supra, sub-heading "Bars to Relief under Section 4 (1) (e)." 
provides that such proceedings shall be dealt with and disposed of in accordance with the law as it was immediately before the coming into force of the Act. ${ }^{179}$

\section{Repeal}

Section 26 repeals statutes and other laws respecting divorce that were in force in Canada or any province immediately before the commencement of the Divorce Act but laws relating to matrimonial causes other than divorce remain unaffected by such repeals. ${ }^{180}$ Indeed, laws relating to such matters as damages for adultery, settlements of property, variation of marriage settlements, and, in general, jurisdiction and powers in matrimonial causes other than divorce are expressly preserved by operation of section 26 (2)..$^{181}$

179 As to the variation or discharge of corollary orders made in divorce proceedings instituted prior to the commencement of the Act, see Divorce Act, $s .25(3)$, discussed supra, n. 147.

180 The Divorce Act, s. 26, reads as follows:

"26. (1) The Dissolution and Annulment of Marriage Act, the Divorce Jurisdiction Act, the Divorce Act (Ontario), in so far as it relates to the dissolution of marriage. and the British Columbia Divorce Appeals Act are repealed.

(2) Subject to subsection (3) of section 19, all other laws respecting divorce that were in force in Canada or any province immediately before the coming into force of this Act are repealed, but nothing in this Act shall be construed as repealing any such law to the extent that it constitutes authority for any other matrimonial cause." See aiso Divorce Act, s. 24, which repeals the Marriage and Divorce Act, supra, n. 109,
ss. 1, 4, and 6.

181 See supra, $n$. 180. For a material change in procedure, however, see Alberta Divorce Rule 563 (3), supra, n. 29, which provides that "no cause of action except for corollary relief under sections 10 and 11 of the Divorce Act shall be joined with a divorce action." 